\title{
Retardation of Chilling Injury Symptoms and Reducing Quality Loss of Cactus Pear Fruits During Cold Storage by Heat Treatments
}

\author{
Ragaa M. El-Saedy $1_{\text {and Nermeen I. El-Naggar }}^{2}$
}

\begin{abstract}
Cactus pear fruits had three ripening stages of light green (G), yellowish green (YG) and yellow (Y) were exposed to water steam (WS) at approximately 78 ?C for one min or dipped into hot water (HW) at 55 ?C for two min or washed with regular tap water(control). Each of the above nine ( 3 stages $\times 3$ treatments) groups was divided into two sections, the first one was stored at 5 ?C and the other was stored at 10 ?C. Heat treatments prolonged the storage period of all ripening stages of fruits. At 5 and $10 ? \mathrm{C}$, respectively, the treated fruits were stored for 32 and 40 days compared with 28 and 32 days for the untreated one. Control fruits were the first to decay due to the chilling injury incidence specially the green stage at 5 ?C and became unattractive as a result of loss of its brightness. On the other hand, heated fruits kept its good appearance, free from decay and wrinkles for longer time. Heat treatments retard the appearance of chilling injury symptoms for the stored fruits at 5 ? C and the best appearance with less chilling symptoms was for the yellow fruits. The fruits stored at 10 ?C were free from chilling symptoms except of small red spots appeared on the control fruits. WS treatment reduced weight loss of cactus pear fruits and the differences were significant for the yellowish green fruits except of those stored at 5 ?C in the first season. On the other side, HW treatment increased the weight loss of all treatments with insignificant differences compared with the control fruits with exception of yellowish green fruits in the second season which reduced it. Green fruits had the highest initial color index (CI) and the heat treatments did not affect $\mathrm{CI}$ of all ripening stages of fruits stored at 5 and $\mathbf{1 0}$ $\mathrm{PC}$ in the two seasons and there were no differences between heat treatments. Heat treatments had no significant effect on pulp weight percent, but generally heated fruits had lower percentages and the fruits stored at $10 ? \mathrm{C}$ had higher percentages with significant increase by the duration of cold storage. At harvest in the two experimental seasons, yellow fruits had the highest contents of juice. Heat treatments had no significant effect on pulp juice weight at 5 and $10 ? \mathrm{C}$ but generally the WS treated fruits had the highest juice weight which may be due to the water loss reduction. Except the green cactus pear fruits which lost its juiciness with the progress of the storage time. At harvest, yellow fruits had the highest values of SSC, V.C, water soluble pectin (WSP) and polyphenoloxidase (PPO) activity and the lowest percentages of acidity. Heat treatments had no significant effect on the SSC of cactus pear fruits except the higher
\end{abstract}

\footnotetext{
${ }_{1}^{1}$ Mamouraa Botanical Garden, Alex., Hort. Res. Center, Giza. Egypt

${ }^{2}$ Dep. Plant Prod. (Pomology), Institute of Efficient Productivity,

Zagazig Nniv.

Received June 29, 2009, Accepted August 24, 2009
}

significant content of heated fruits in some intervals. Heat treatments had significant effect on acidity and V.C especially the WS treatment which had the highest values at the two storage temperatures and in two seasons. Heat treatments had significant effect on reducing WSP pulp content and the activity of PPO. In both seasons, SSC of all treatments decreased by the advancing of cold storage and the highest values were obtained from yellow fruits. Fruit acidity increased by the end of the cold storage at 5 $\mathfrak{X}$ and after the same period at 10 C (32 days), then decreased at the last two intervals at 10 ?C. WSP content increased with the loss of fruit firmness and the lowest changes were obtained with the yellow fruits and the fruits stored at 5 ?C. PPO activity increased, then decreased after 24 days at 5 and 10?C.

\section{INTRODUCTION}

Cactus pear or tuna fruit (opuntia ficus indica) is a berry fruits with a number of small hard seeds. The pericarp and the edible pulp may have soft green, greenish, white, canary yellow, lemon yellow, red or purple hues (Stinzing et al. 2001). The nutritional importance of cactus pear fruits is mainly due to its antioxidant properties and its contents of ascorbic acid $(25-30 \mathrm{mg} / 100 \mathrm{~g})$. The major components of the fruit pulp are water $(85 \%)$ and carbohydrates $(10-15 \%)$ with $12-15 \%$ sugars; $0.6 \%$ protein and $0.1 \%$ lipids; $490 \mathrm{ppm}$ calcium; $2200 \mathrm{ppm}$ potassium and $850 \mathrm{ppm}$ magnesium (Duru and Turker, 2005; Pérez et al., 2005 and Cantwell, 1995).

Cactus pears are non climacteric fruits having at 20?C a low respiration rate $\left(20 \mathrm{ml} \mathrm{CO} \cdot \mathrm{Kg}^{-1} \cdot \mathrm{h}^{-1}\right)$ and low ethylene production $\left(0.2 \mu \mathrm{l} \mathrm{C} \mathrm{H}_{4} \cdot \mathrm{Kg}^{-1} \cdot \mathrm{h}^{-1}\right)$ and so, their physiological activity is low. Therefore, the perishability of fruits lies not in their physiology but mainly in physical damage. The low activity and the high sugar content of the pulp make the cactus pear fruit very susceptible to microbial invasion and limit its storage life.Under marketing conditions (20 ?C, 60 - 70 $\% \mathrm{RH})$ fruits have a shelf life of only few days which is mainly affected by decay at the stem end and related to physical damage during harvest and handling. Another problem during post-harvest handling of cactus pears is weight and water loss because it decrease saleable weight and appearance (Cantwell, 1995 and Garcia et al., 1997). 
Cold storage reduces water loss by reducing the vapor pressure deficit and increases the post-harvest life of most horticultural crops by retarding respiration, ethylene production, ripening, senescence, undesirable metabolic changes and decay. However, cactus pears are susceptible to chilling injury when stored at temperature below 10 ? depending on cultivar, environmental growth condition and fruit age (Cantwell, 1995; Garcia et al., 1997 and Schirra et al., 1999).

Post-harvest decay losses are commonly controlled by fungicides but public concern on possible food poisoning by chemical residues has led to the using of the physical methods that are less hazardous to human health such as heat treatments which controlled both of decay and chilling injury. The beneficial effects of heat treatments on keeping quality of fruits are associated with induction of heat shock proteins (Paull and McDonald, 1994), increasing in internal $\mathrm{CO}_{2}$, decreasing in internal $\mathrm{O}_{2}$ and decreasing in ethylene forming enzyme activity (Mitcham and McDonald, 1993 and Zainon et al., 2000). Also, reducing the rate of fruit texture changes as a result of reducing the activity of softening enzymes (Zainon et al., 2000), maintaining membrane stability (Chein, 2000) and reducing the solubility of polyuronide (Lazan et al., 1989 and Shalom et al., 1993).

The objectives of this study were to investigate the influence of pre-storage heat treatments (hot water and water steam) and the following different cold storage temperatures on the chilling injury, decay incidence and other quality attributes (fruit quality and storagability, external color index, weight loss, pulp juice weight, SSC, acidity, water soluble pectin and pulp PPO activity) of cactus pear fruits at different ripening stages.

\section{MATERIALS AND METHODS}

Cactus pear fruits had three ripening stages of light green $(\mathrm{G})$, yellowish green $(\mathrm{YG})$ and yellow $(\mathrm{Y})$ were manually and carefully harvested on the last days of July in 2007 and 2008 seasons from a private orchard that located in EL-Nobaria, Alexandria province. Cactus pears were immediately transported to the Post-harvest Center of Horticulture Crops, Faculty of Alexandria, Alexandria University.

Fruits were sorted for size uniformity and absence of defects. Sound selected fruits of each ripening stage (fig. 1) were divided into three groups (150 fruits of each). The first group was exposed to water steam (WS) at approximately $78 ? \mathrm{C}$ for one min then dried. The second group was dipped in hot water (HW) at 55 ?C for two min then dried. The peel area temperature was recorded each $15 \mathrm{sec}$. during WS and HW treatments and it reached the values (a range of 5 records) of 43 , 45 and $46.2 ?$ C for WS heated fruits and 40.4, 60.2 and 70.0 ? $\mathrm{C}$ for HW treated fruits respectively for the G, YG and $\mathrm{Y}$ stages. The third group of fruits was washed using regular tap water then dried (control). Each of the above nine (3 stages $\mathrm{x} 3$ treatments) groups was divided into two sections, packed in open plastic boxes, for each treatment represented 3 replicates. Each one contained 30 fruits and the dimensions of the boxes were $60 \times 40$ x $20 \mathrm{~cm}$., the first one was stored at 5 ?C and the other was stored at 10 ?C.

Ten cactus pear fruits from each ripening stage were taken to determine the initial physical and chemical properties of the fruits. Changes in such properties were followed up each four days intervals through the experimental period. 15 fruits were labeled in every treatment and were initially weighed to calculate the fruits weight loss percent during the cold storage in relation to its original weight.

Chilling injury incidence and external fruit appearance were estimated visually at each sampling interval. External color of the fruits was estimated visually and measured with Minolta colorimeter. L, a and $b$ values were used to calculate a color index (CI) of each fruit in the sample of each treatment according to Dominguez, (1992) as follow:

$\mathrm{CI}=\mathrm{ab} / \mathrm{L}$ ( $\mathrm{a}, \mathrm{b}$ and $\mathrm{L}$ were Minolta's reading)

Each fruit in the sample was weighed then peeled. The pulp of each fruit was weighed then squeezed and the obtained juice was weighed. The obtained juice was used to determine the percentage of soluble solids content (SSC) by the use of a hand refractometer and the titratable acidity was determined in the obtained juice as g citric acid /100 ml juice according to Chen and Mellenthin (1981).

Water soluble pectin (WSP) of fruit pulp was estimated as Ca pectate according to AOAC, (1980).

Polyphynoloxidase (PPO) activity was determined in the crude extracts (Brenneman and Black, 1979) of three samples of fruit pulp in each replicate, each treatment and the activity was measured using the method of Matta and Dimond (1963).

The termination of the experiment was done by the incidence of chilling injury symptoms and the loss of good fruit appearance. All data obtained were statistically analyzed according to the methods described by Snedecor and Cochran (1980). The individual comparisons were carried out by using the Least Significant Difference (LSD) according to SAS Institute (1985). Simple regression coefficient between 
storage period and studied properties was calculated using SAS program (1985).

\section{RESULTS AND DISCUSSIONS}

\section{Fruit Quality and Storability:}

Fig. 1 howed the initial quality of cactus pear fruits. In the first season, the fruits had the initial weight of $131.9,133.7$ and $138.0 \mathrm{~g}$, the diameter of 5.5, 5.4 and $5.7 \mathrm{~cm}$ and the height of $7.45,8.4$ and $8.9 \mathrm{~cm}$, respectively for the green, yellowish green and yellow fruits. Those values in the second season respectively were 147.7, 150.3 and $156.9 \mathrm{~g}$ for weight, 5.5, 5.5 and $5.7 \mathrm{~cm}$ for diameter and 8.5, 9.0 and $9.0 \mathrm{~cm}$ for height.

Heat treatments prolonged the storage period of all ripening stages of cactus pear fruits compared with untreated fruits. At 5 and 10 ?C, respectively the treated fruits stored for 32 and 40 days compared with 28 and 32 days for the control. Control fruits were the first to decay (fig 5) due to the chilling injury incidence, specially the green one at 5 ?. Untreated fruits became unattractive as a result of loss its brightness in color and the formation of wrinkles with the drying of the fruit ends and the flatness loss of the rose end (fig 6). On the other hand, heated fruits kept its good appearance free from decay and wrinkles for longer time.

Harvest damages to the peel and stem end of cactus fruits lead to attack by numerous pathogens and result in fruit decay. Common post-harvest pathogens on cactus fruits are mostly fungi and include Fusarium spp., Alternaria spp. and Penicillium spp. Heat treatment reduce that decay by killing pathogens spores and furthermore, the partial melting of the epicuticular wax layer in wounded areas with concomitant occlusion of possible entry points for wounded pathogens may have produced additional protection against decay in cactus pear fruits (Cantwell 1995; Piga et al., 1996 and Schirra et al., 1999).

\section{Chilling Injury Incidence:}

Cactus pear fruits are chilling sensitive when exposed to temperature below 9-10 ? for longer than a few days. Chilling injury symptoms include pitting, surface bronzing and dark spots on the peel and increased susceptibility to decay (Cantwell 1995 and Garcia et al., 1997).

In this experiment, heat treatments retard the appearance of chilling injury symptoms for the stored fruits at 5 ?. Chilling injury incidence began after 12 days at 5 ?C first on the control as bronze pitting (fig 2). After 16 days, those symptoms area increased (1-2 mm) and began to appear on the heated green fruits and the best appearance with less symptoms was obtained for the WS treated fruits. Chilling injury symptoms appeared later ( 24 days) on the yellowish green and the yellow fruits and the control fruits were the most sensitive to low temperature. With the advancing of the storage period Chilling symptoms increased (fig 3) to include all the control fruit surface and $100 \%$ of the fruits. Those symptoms include less area of the fruit surface of the treated green fruits $(50 \%)$ on less number of the fruits $(75 \%)$. The yellowish green treated fruits had better appearance of the fruit surface $(25 \%)$ on less number $(50 \%)$ and the best appearance with less chilling symptoms $(>25 \%$ of the fruit surface on $>30$ of the fruit number) was for the yellow fruits.

The fruits stored at $10 ? \mathrm{C}$ were free from chilling symptoms except of small red spots (1-2 mm) appeared on the control fruits (fig 4). The chilled areas were suitable places to decaying pathogens with the progress of the storage period (fig 5).

Chilling injury of cactus pears varies depending on species, cultivars, fruit maturity, environmental growth conditions and storage humidity (Schirra et al., 1999). Chilling injury appeared after 14 days at $9 ? \mathrm{C}$ on $O$. ficus-indica Gialla fruits (Chessa and Barbera, 1984) and the occurrence of chilling injury decreased when the fruits get its orange color (Gorini et al., 1993) where the ripe fruits is less susceptible to chilling injury than the fruits harvested at the green or breaker stage (Schirra et al.,1999).

Cactus pear fruits are reported to be relatively less sensitive to chilling injury and they could be stored at 0?C for up two months (Berger et al.,1978 and Cantwell, 1995) while Copena-Torreoja fruits had 100 $\%$ injury from chilling after the first month of cold storage at 9 ?C (Garcia, 1997).

Several post-harvest treatments have shown to reduce chilling injury during storage. Those fore cactus pears include post-harvest heat treatments (Felix, 2002) which reduce the incidence of chilling injury as a result of inducing of heat shock proteins, suppressing oxidative activity and maintaining membrane stability (Chein, 2000 and Zainon et al., 2000).

Moisture loss may be an important factor involved in cactus pear chilling injury development. A reduction in water loss result in a delay of membrane collapse occurring in chilling sensitive fruits when exposed to low temperature (Piga et al., 1996 and 1997).

\section{Fruit Weight Loss \%:}

The obtained data in the two seasons (Tables 1 and 2) showed that WS treatment reduced weight loss of cactus pear fruits and the differences were significant for the yellowish green fruits except of those stored at 5 
C in the first season. On the other hand, HW treatment increased the percentage of fruit weight loss of all treatments with insignificant differences compared with the control fruits but the same treatments reduced the weight loss of yellowish green fruits in the second

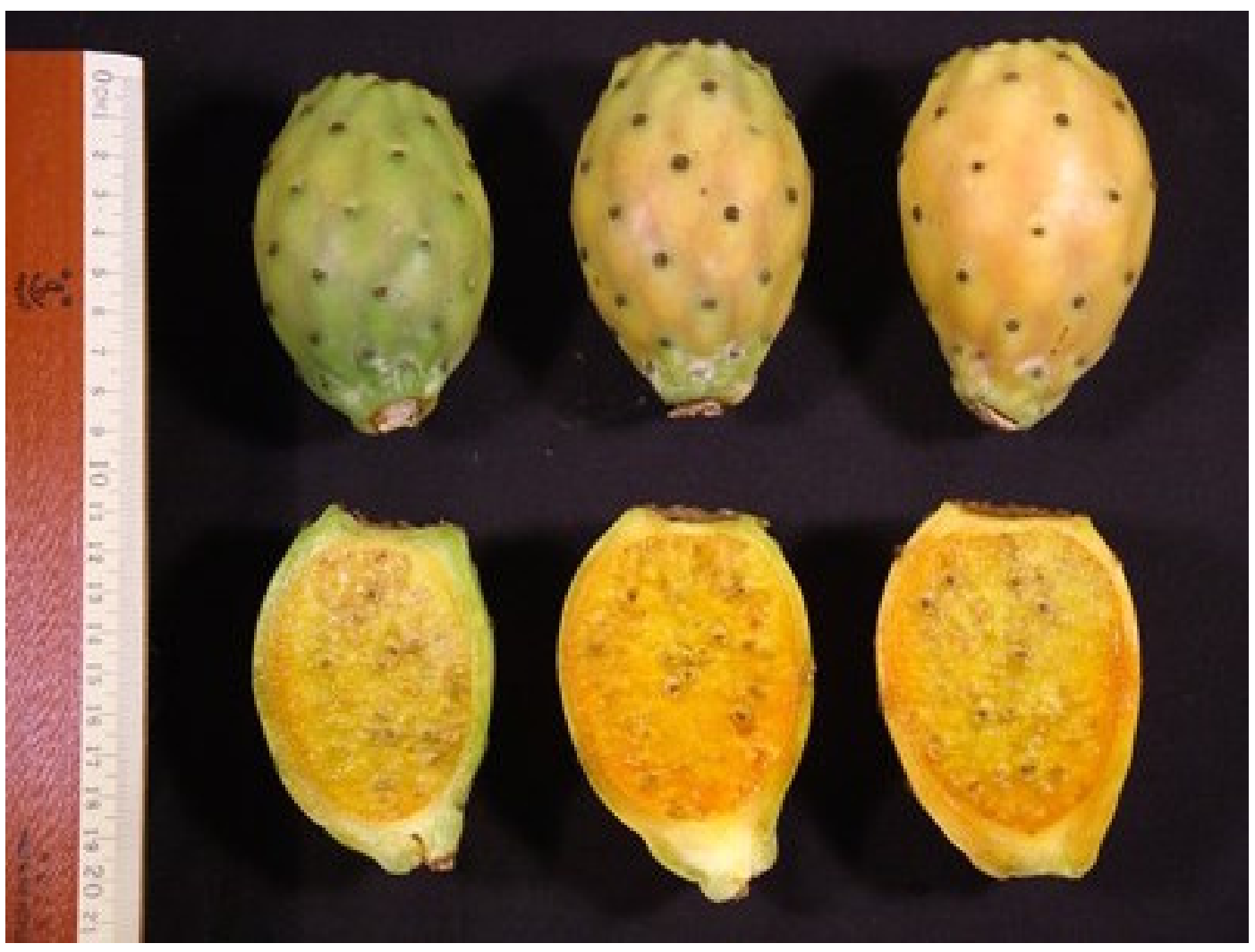

Fig 1. Initial quality of cactus pear fruits 


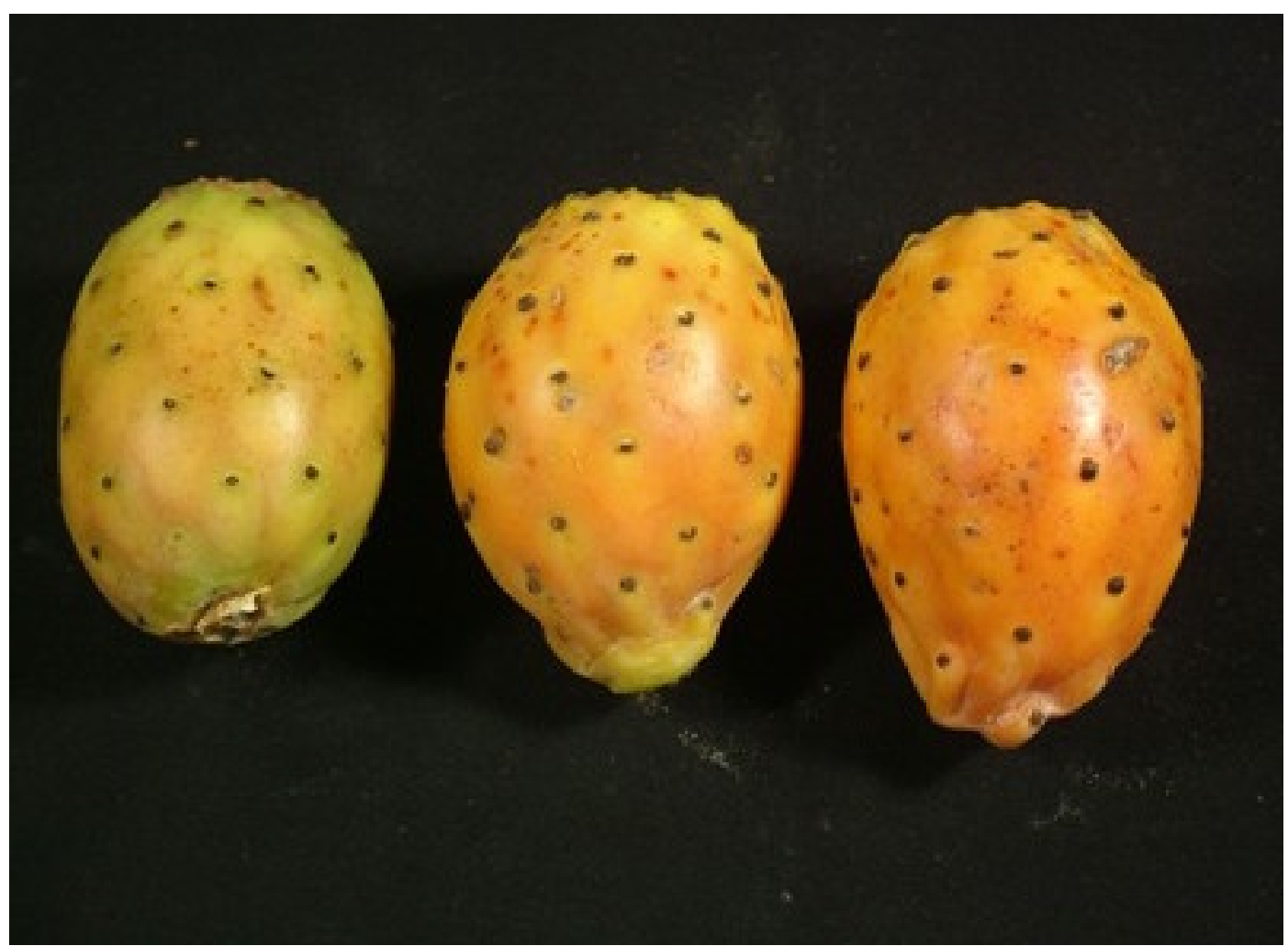

Fig 2. Initial symptoms of chilling injury of control fruits stored at 5?C 


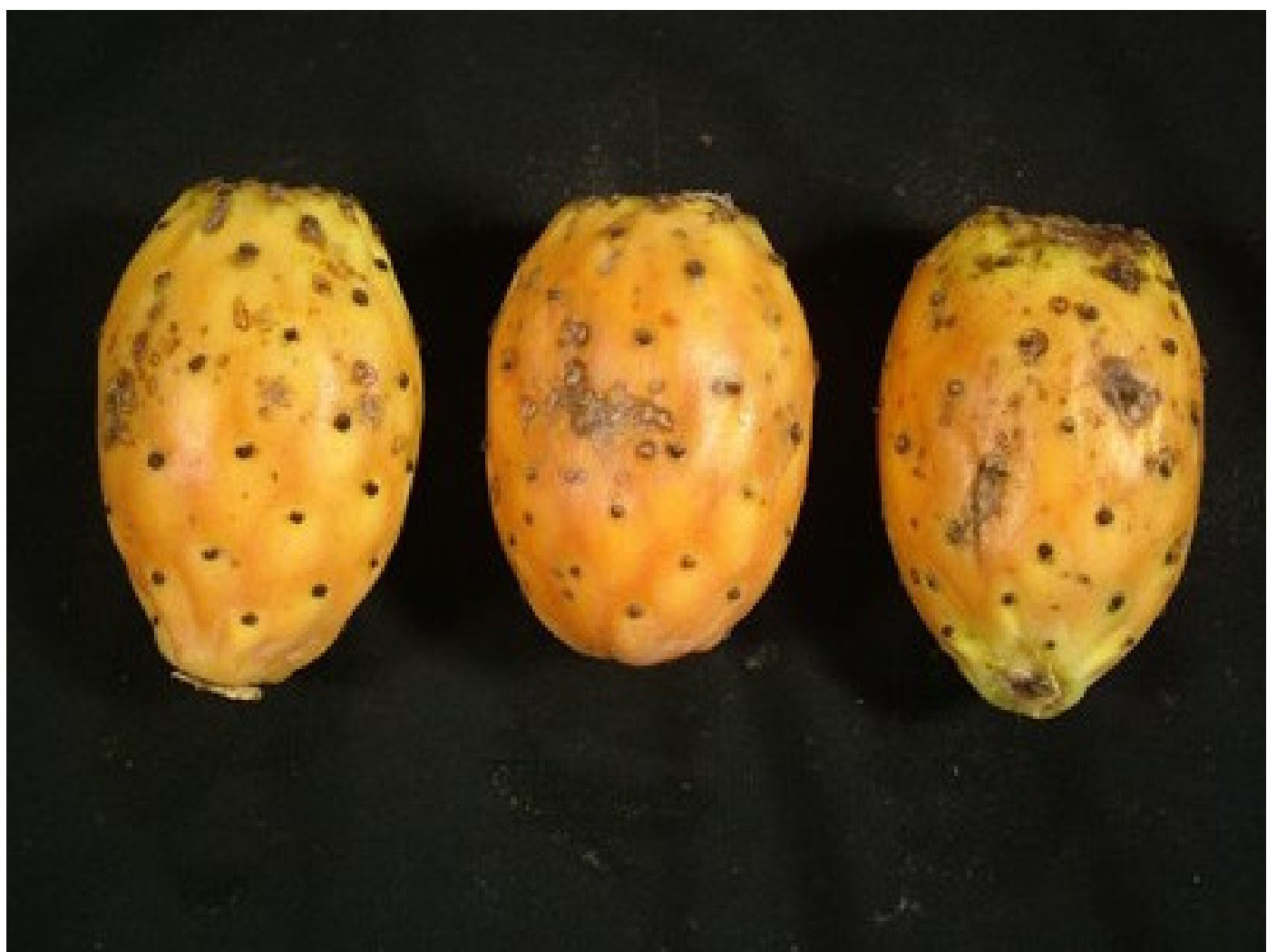

Fig 3. Advanced chilling injury symptoms of control fruits stored at 5?C

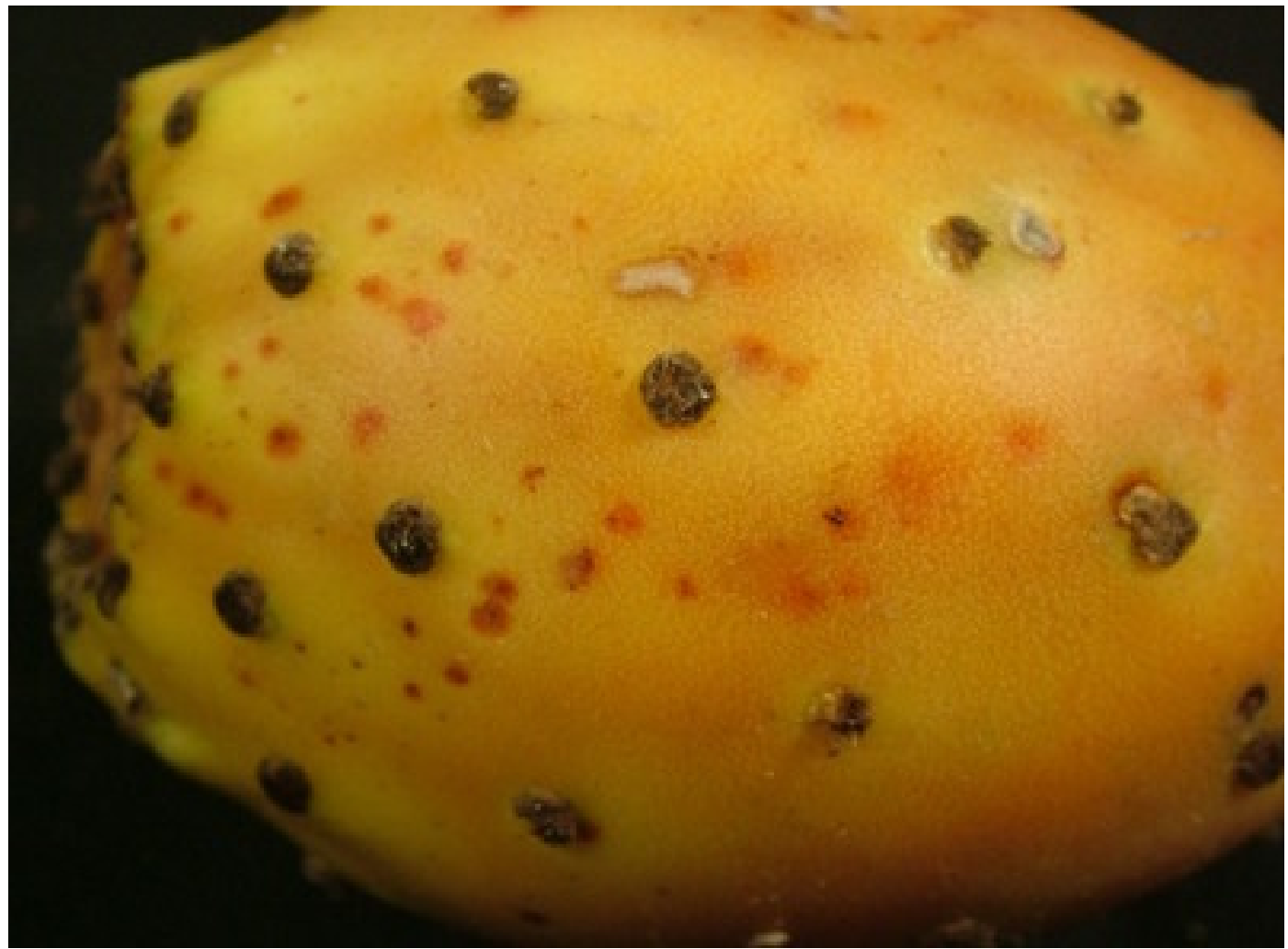

Fig 4. Red spots appearance of control fruits stored at 10?C 

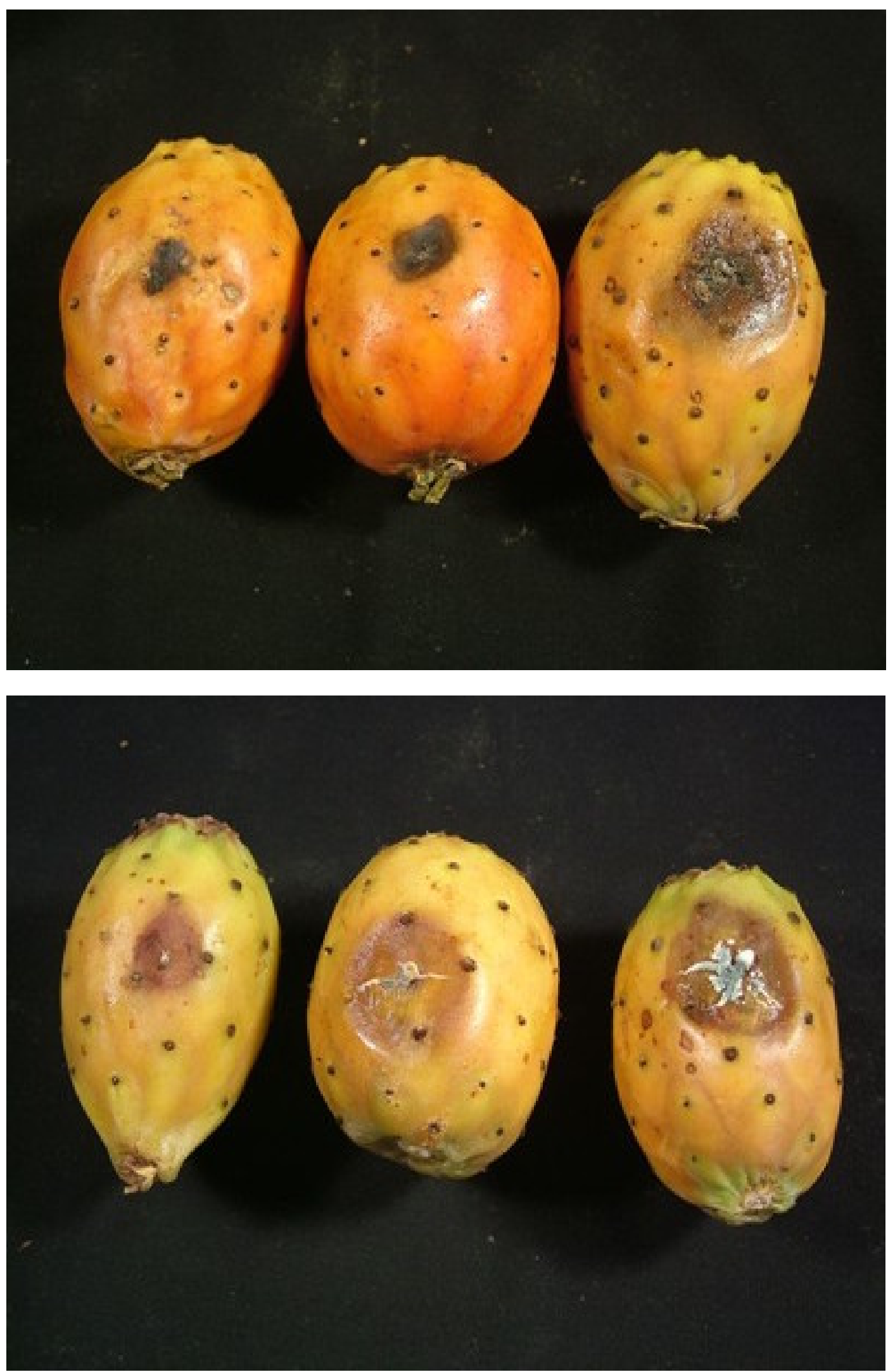

Fig 5. Decay incidence on chilled areas of fruits stored at 5?C 

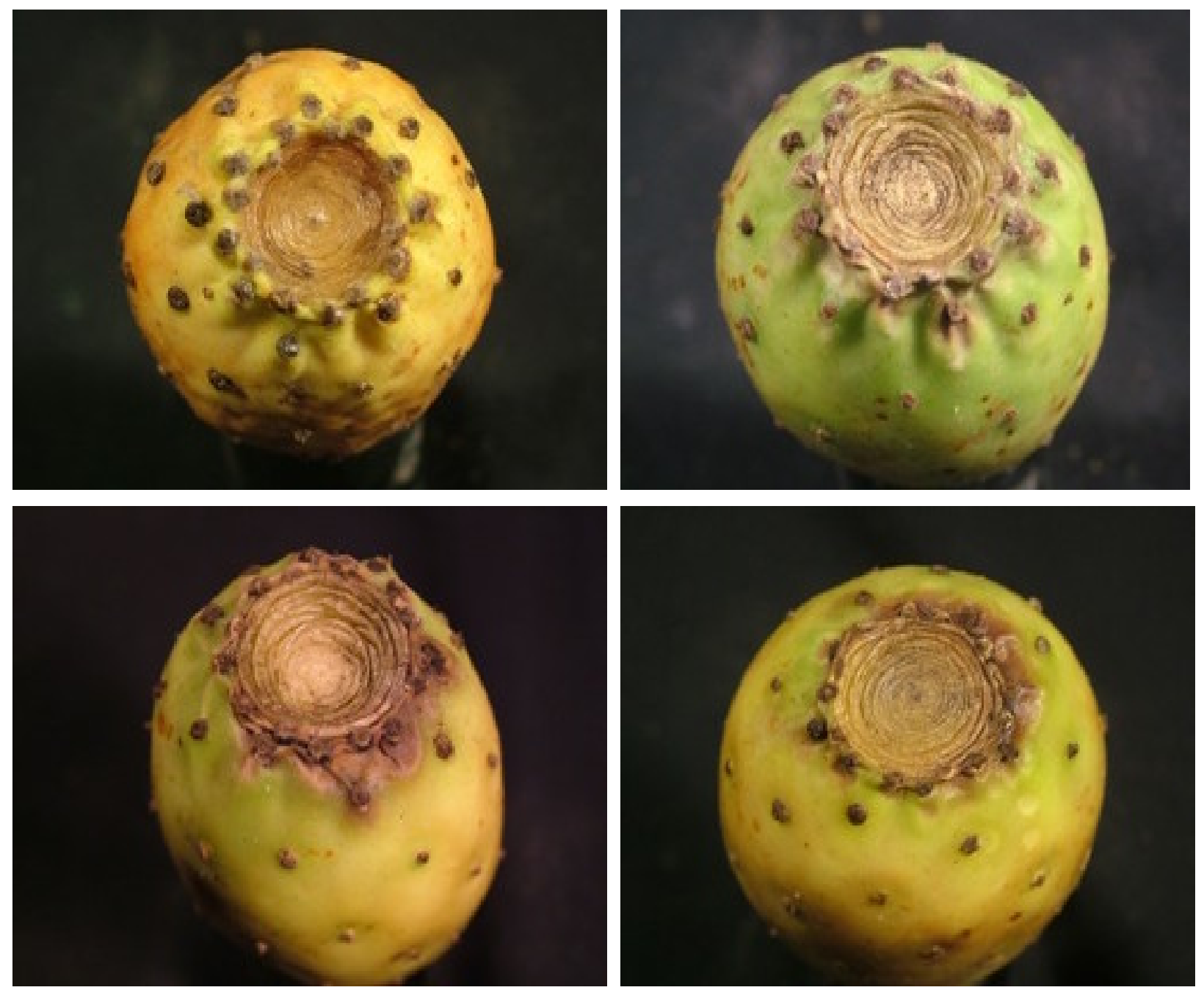

Fig 6. Rose end wrinkles on fruits stored at 10 wrinkles ?C.

season. The stored fruits at 10 ? $\mathrm{C}$ had the significant higher weight loss compared with those stored at 5 ?C. By the progress of the storage period in two seasons, there was a significant increase $\left(r^{2}\right.$ values were highly significant) of weight loss of all treatments.

Weight loss or water loss is a serious problem for cactus pear fruits because it decreases saleable weight and appearance (Cantwell 1995 and Garcia et al., 1997) and a weight loss of about $8 \%$ was necessary to affect visual appearance of cactus pear fruits (Félix et al., 1992 and Lopez et al., 2003). The resulting increase of weight loss in water heated fruits is due to the stress condition of the treatment on fruits (Philips, 1982). Storage at lower temperature (5 ?C) reduces water loss by reducing the vapor pressure deficit (Cantwell, 1986) and that loss increases by the duration of cold storage (Schirra et al. ,1999 and Lopez et al., 2003) with the decrease of its rate may be due to changes in structure and morphology of epicuticular waxes (Chessa et al., 1992 and Lopez et al., 2003).

\section{External Color Index:}

The tabulated data (Table 3 and 4) showed the tendencies of external color changes as color index (CI) of heated cactus pear fruits compared with control ones. Heat treatments did not affect CI of all ripening stages of fruits stored at 5 and $10 ? \mathrm{C}$ in two seasons and there were no differences between heat treatments. Green fruits had the highest initial CI and its change percentages after 28 days ranged from 33.58 to $65.23 \%$. On the other hand, yellow fruits had the lowest initial $\mathrm{CI}$ and the highest change percentages after 28 days ranged from 28.57 to $77.55 \%$. The above data are associated with those of Schirra et al., (1997); Ortùzar, (1976); Castillo, (1997).

The visual observations of the fruits external color in this work showed that peel color changed with the 


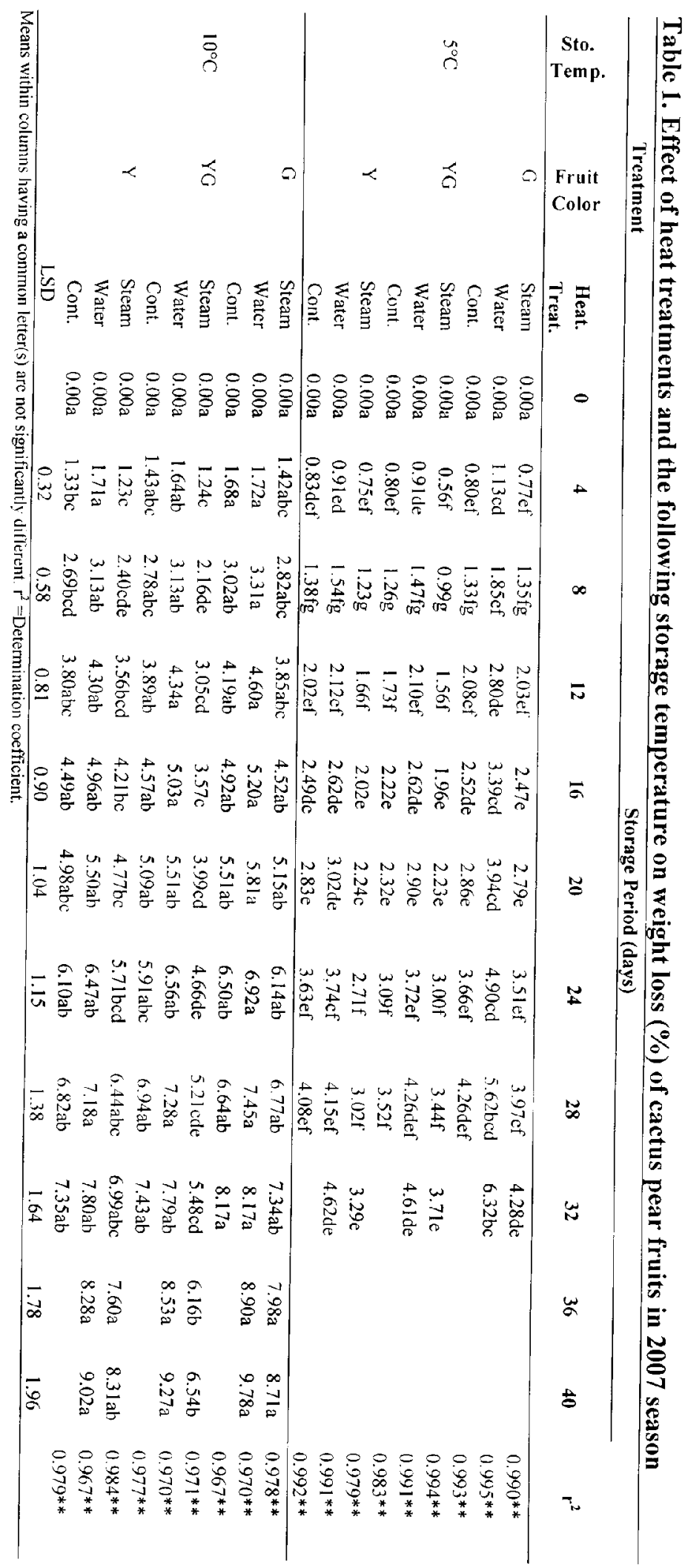




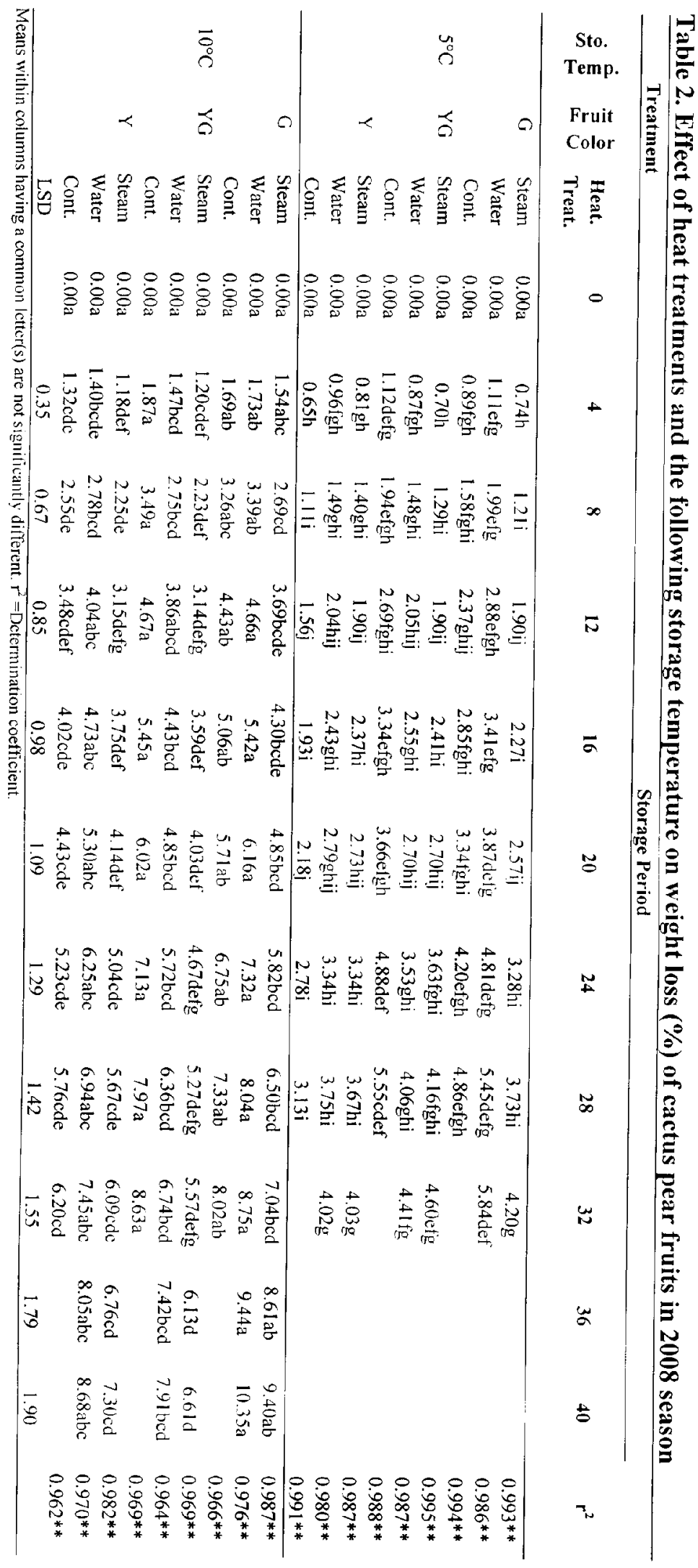




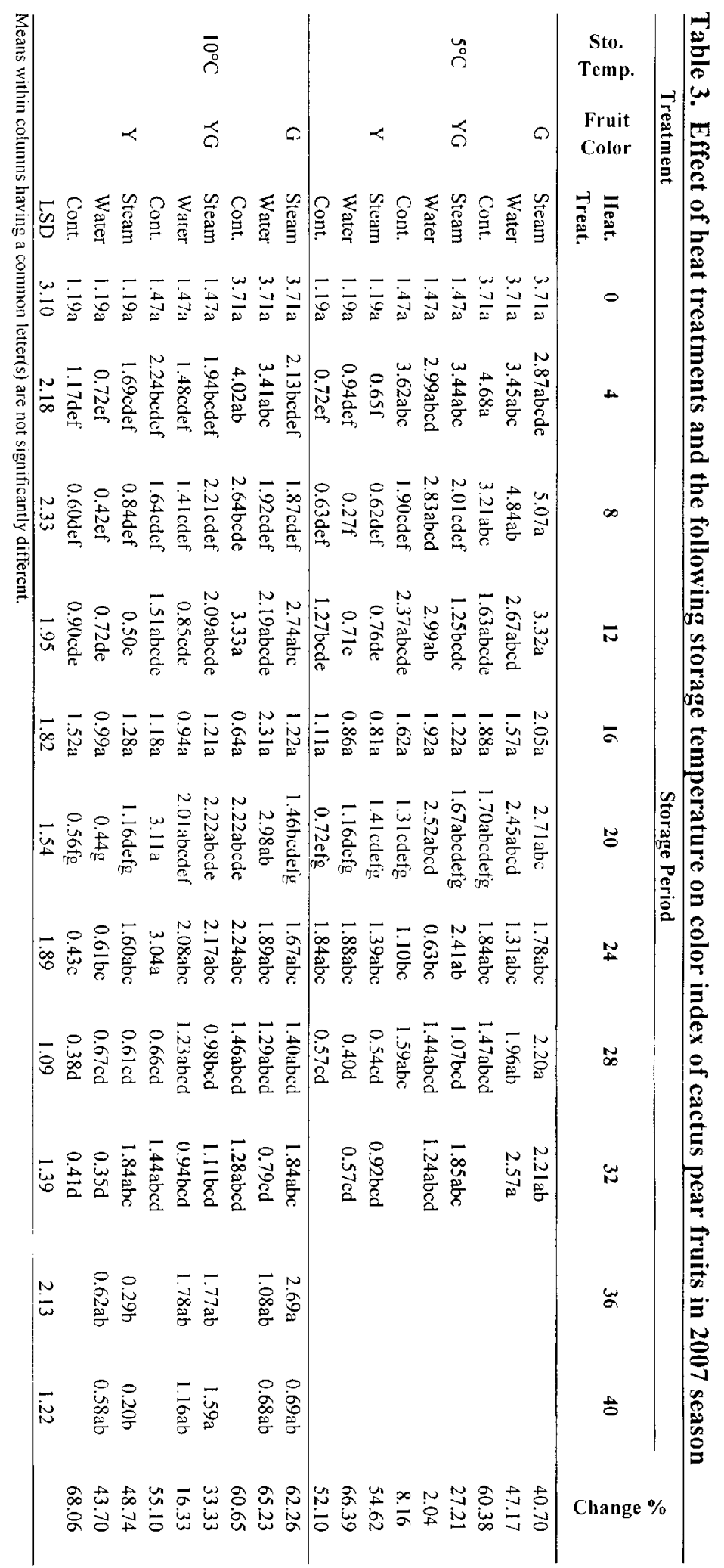




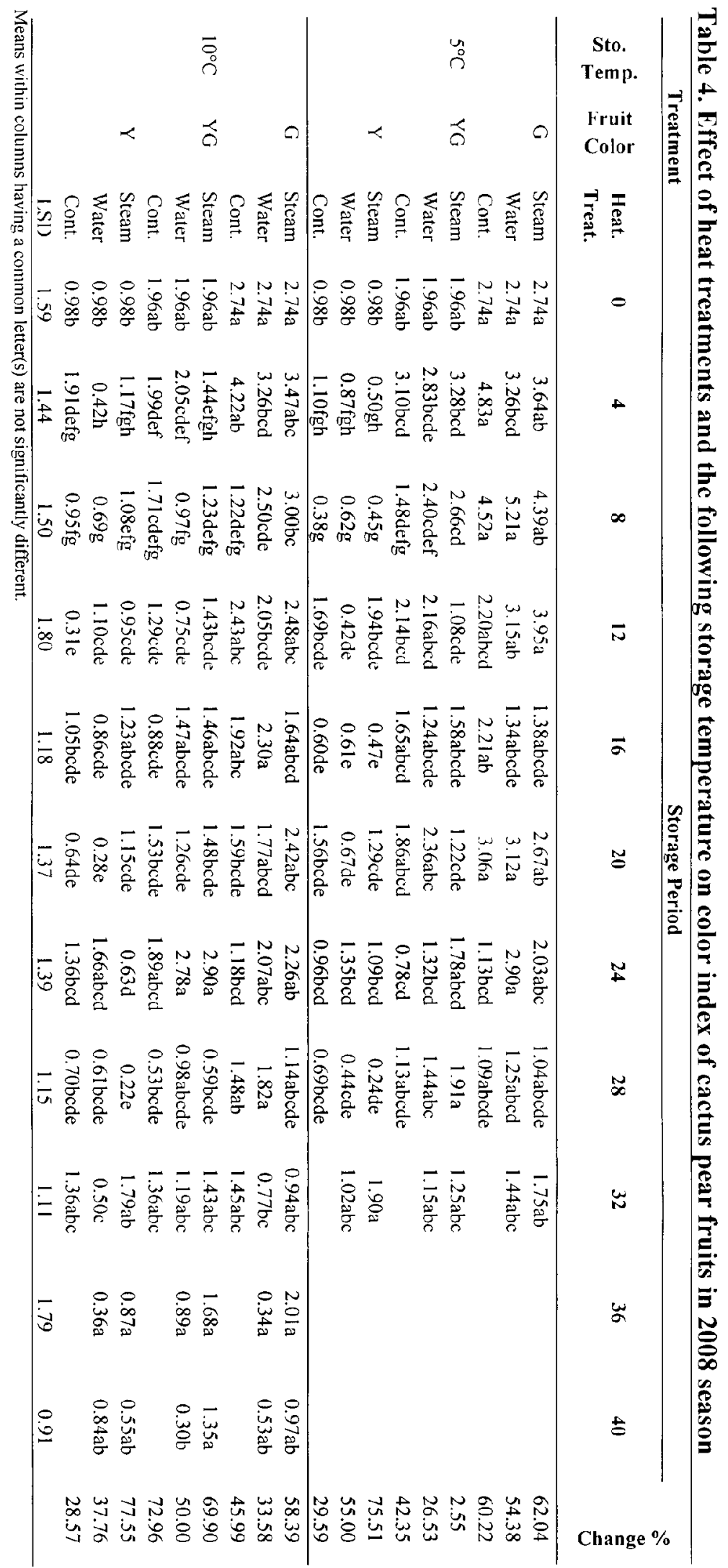


progress of the storage period and that was faster at 10 ?C. The green fruits changed to the yellowish green and the yellowish green fruits changed to the yellow color while the yellow ones changed to the orange color. Lopez et al., (2003) reported that Naranjona cactus pear fruits developed yellow-orange skin coloration at store whereas, Charola fruits skin color essentially remained as it was at harvest.

The color is one of the main attributes of cactus pear fruits, which can determine the consumer acceptability and serving as an indicative of the harvest point of some fruits (Silva et al., 2009). Pérez et al., (2005) reported that the changes in carotenes and xanthophylls contents are somewhat related to the ripening period of cactus pear fruits. Silva et al., (2009) accessed cactus pear fruits color each 3 days storage by a Minolta colorimeter through the parameter $\mathrm{L}^{*}, \mathrm{C}^{*}$ and $\mathrm{H}^{*}$ and found that lightness $\left(\mathrm{L}^{*}\right)$ declined during storage but Lopez et al., (2003) reported that lightness $\left(\mathrm{L}^{*}\right)$ did not change significantly.

\section{Pulp Juice Weight \%:}

The pulp juice weight as percentages of the pulp weight are tabulated in tables 5 and 6 . At harvest in the two experimental seasons, yellow fruits had the highest contents (89.94 and $88.56 \%$ ) of juice compared with the yellowish green $(84.01$ and $80.27 \%$ ) and the green fruits $(76.64$ and $73.91 \%)$. In the two seasons, heat treatments had no significant effect on pulp juice weight at 5 and $10 ? \mathrm{C}$ but generally the WS treated fruits had highest juice weight which may be due to the water loss reduction. Except the green fruits cactus pear lost its juiciness with the progress of the storage time at 5 and $10 ?$ due to the water loss but the changes $\left(r^{2}\right.$ values) were not significant.

\section{SSC \%:}

At harvest, yellow fruits had the highest (12.47 and $12.675 \%$ ) SSC percent (Table 7 and 8) then the yellowish green (12.27 and $12.33 \%$ ) and the green ones (12.00 and $11.93 \%$ ) with no significant differences in the two seasons. Generally, heat treatments had no significant effect on the SSC of cactus pear fruits except the higher significant content of yellowish green heated fruits at the intervals of 12 and 16 days at 5 ?C and 20 and 24 days at 10 ?C, in the first season. Also, at the intervals of 16 and 20 days for yellow fruits at 5 ?C and the green ones at $10 ? \mathrm{C}$ and of 20 and 24 days for the yellowish green fruits stored at 10 ?C. The above results agree with the results of Schirra et al., (1999).

SSC of all treatments decreased with the duration of cold storage at 5 and 10 ?C in the two seasons except the highest values obtained from yellow fruits at the end of storage at 10 ?C. These results of decreasing SSC with storage agree with Garcia et al., (1997).On the other hand, Lopez et al., (2003) found an increase in SSC of cactus pear fruits by storage at 18 ?C. The changes in SSC, although generally are useful as an approximation of sugar content, do not necessarily correlate well with changes in sugar content (Cantwell, 1995). These changes are related to starch synthesisdegration, depending on starch and sugar content in the fruit at harvest (Lopez et al., 2003).

\section{Titratable Acidity \%:}

In the two experimental seasons, yellowish green fruits had the highest significant citric acid content (Tables 9 and 10). Heat treatments had significant effect on fruit pulp acidity especially the WS treatment which had the highest values at the two storage temperatures and in two seasons. The higher content of citric acid in heated fruits may be due to the effect of heat treatment on regulating respiration and perhaps other metabolic processes during storage. The above results and associated discussion agree with the results on papaya (Lazan et al., 1989 and El Naggar and El Saedy, 2004) and cherimoya fruits (Undurraga et al., 1995 and El Saedy, 2005). On the other hand, Schirra et al., (1999) and Berger et al., (2002) reported that heat treatment had no significant effect on cactus pear acidity.

Fruit acidity increased by the end of the cold storage at $5 ? \mathrm{C}$ and after the same period at $10 ? \mathrm{C}$ (32 days) then decreased at the last two intervals at $10 ? \mathrm{C}$ $\left(\mathrm{r}^{2}\right.$ values were not significant). Cantwell, (1995) and Pérez et al., (2005) reported that citric acid decreased during ripening of cactus pear fruits. On the other hand, Piga et al., (2003) reported a significant increase of cactus pear acidity after cold storage.

\section{Water Soluble Pectin (WSP) \%:}

At harvest in the two seasons, green fruits had the lowest WSP content $(0.21$ and $0.22 \%)$ then yellowish green $(0.22$ and $0.24 \%)$ and yellow $(0.30$ and $0.31 \%)$ fruits with no significant differences (Tables 11 and 12). In both seasons, heat treatments had significant effect on WSP of cactus pear fruits where the heated fruits contained lower values compared with control fruits. That finding may be due to the effect of heat treatment on regulating metabolic processes and the activity suppression of softening enzymes (Chein, 2000 and Zainon et al., 2000). With the advancing of cold storage, WSP content increased with the loss of fruit firmness and the lowest changes were obtained with the yellow fruits and the fruits stored at 5 ?C. 


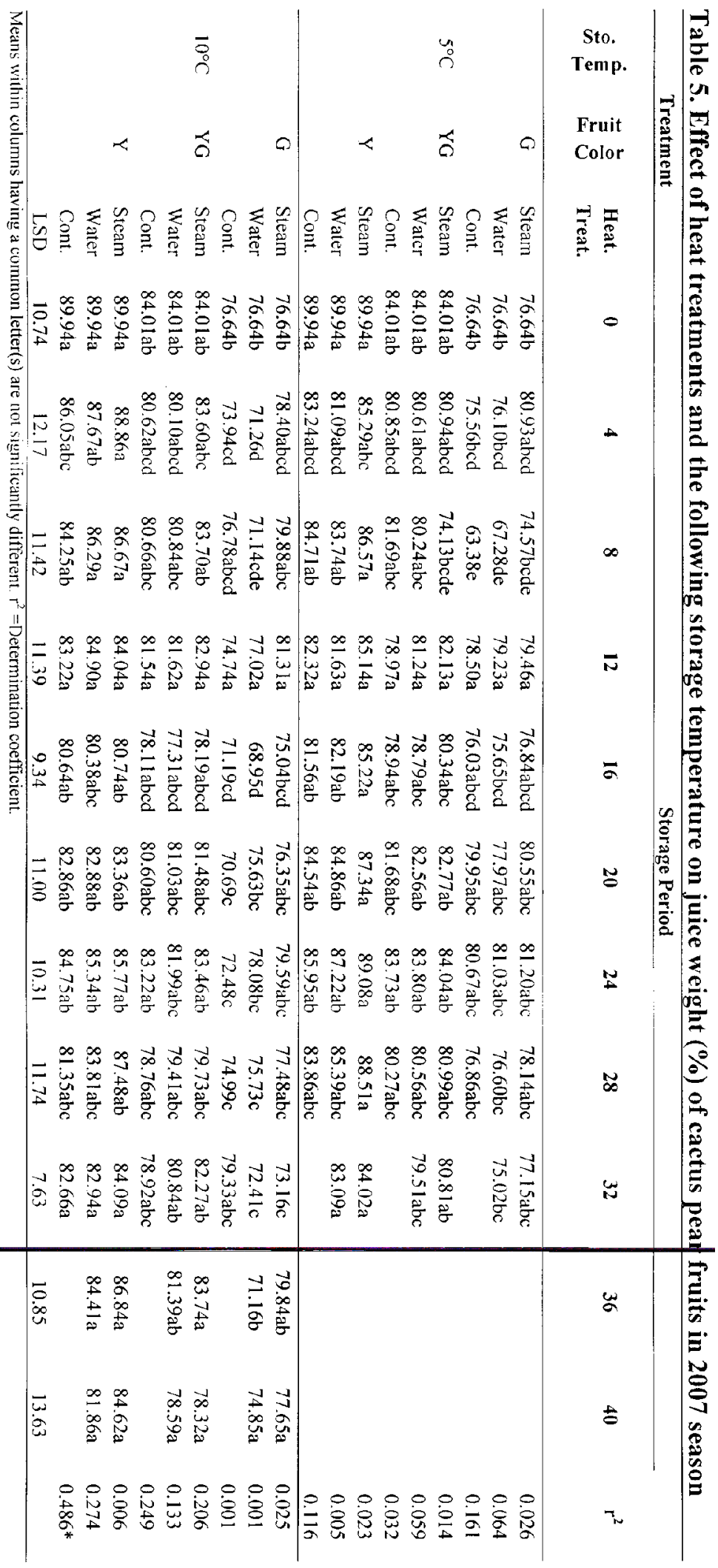




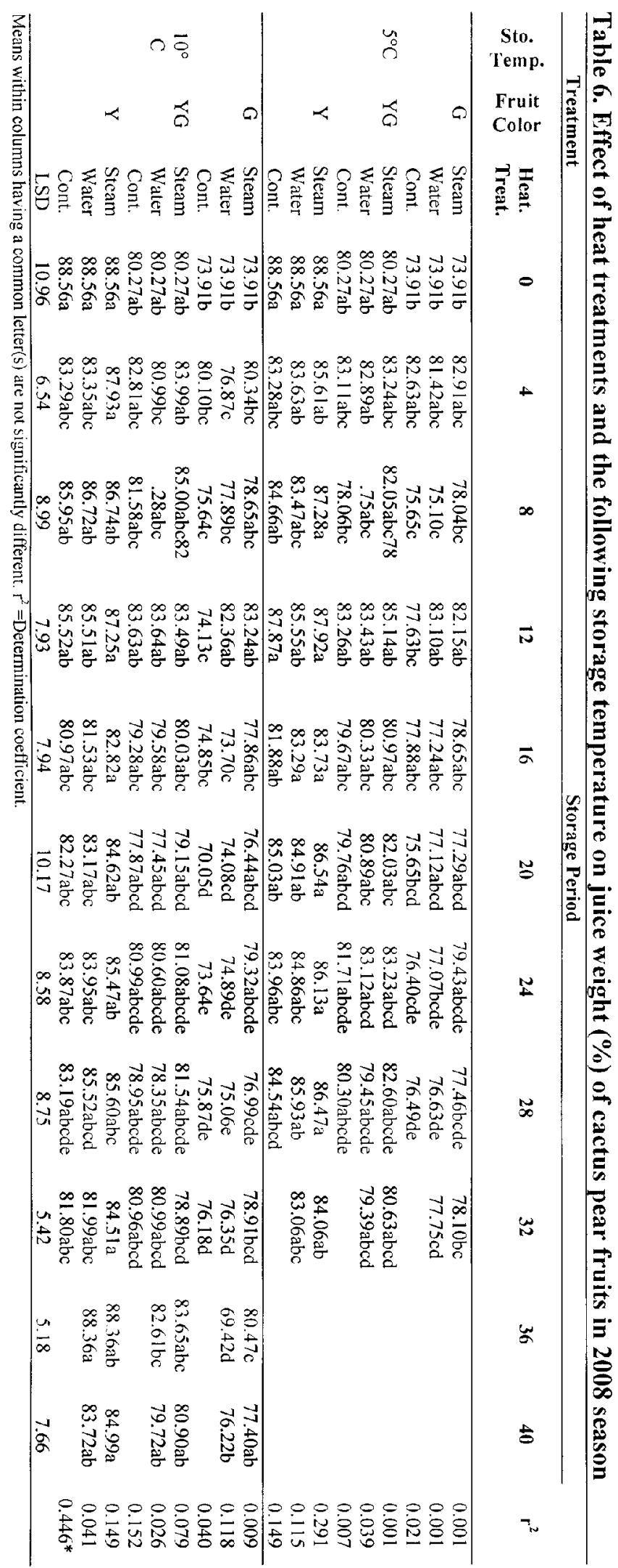




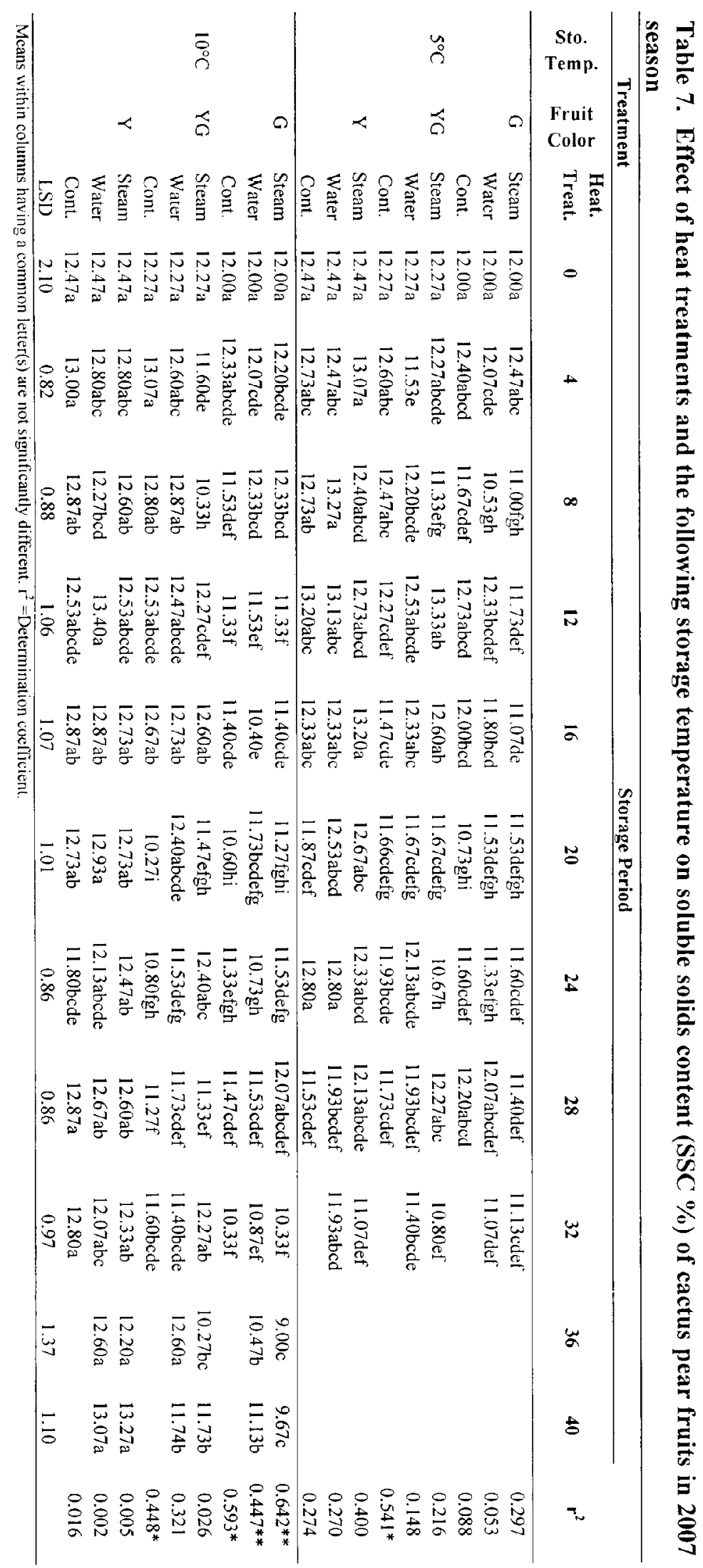




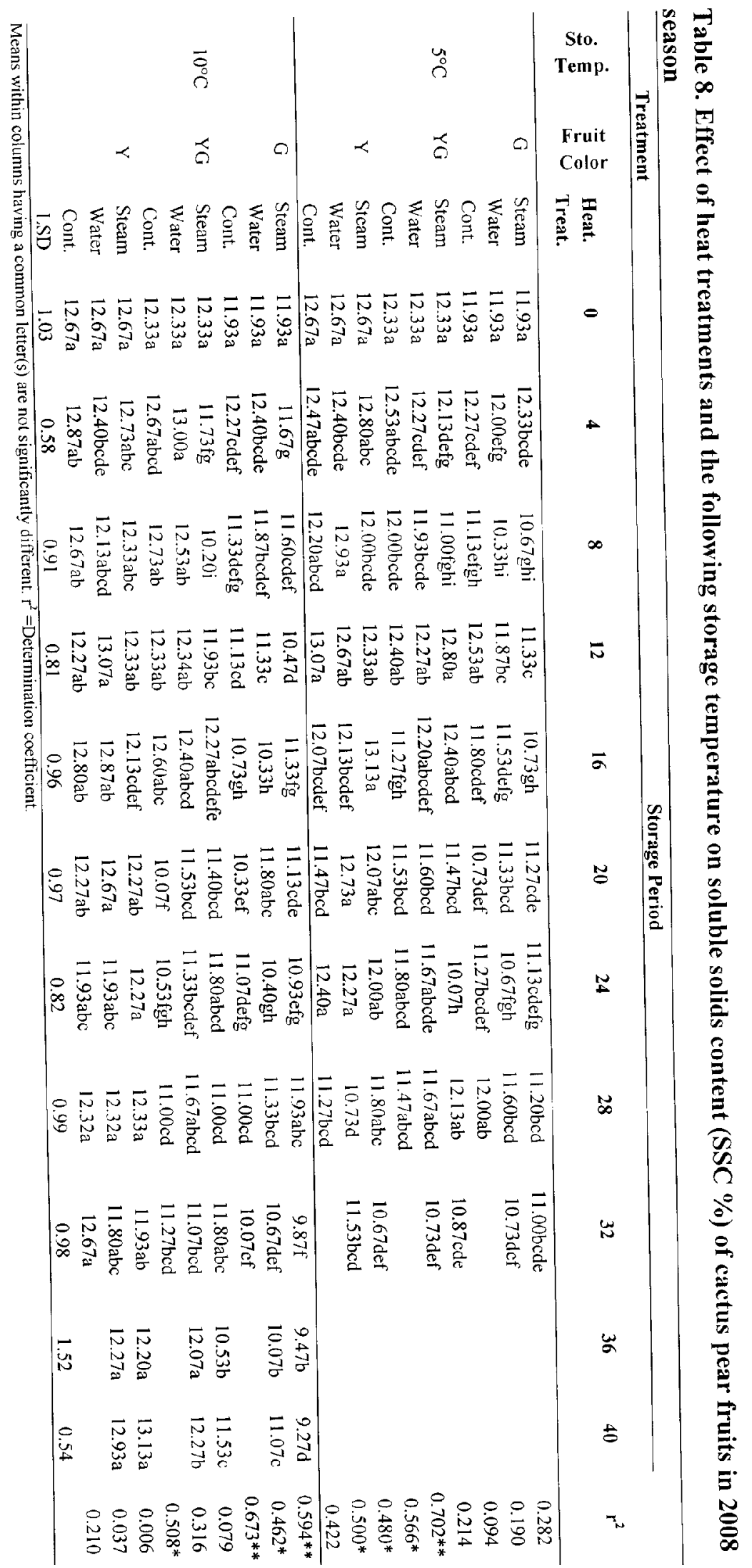




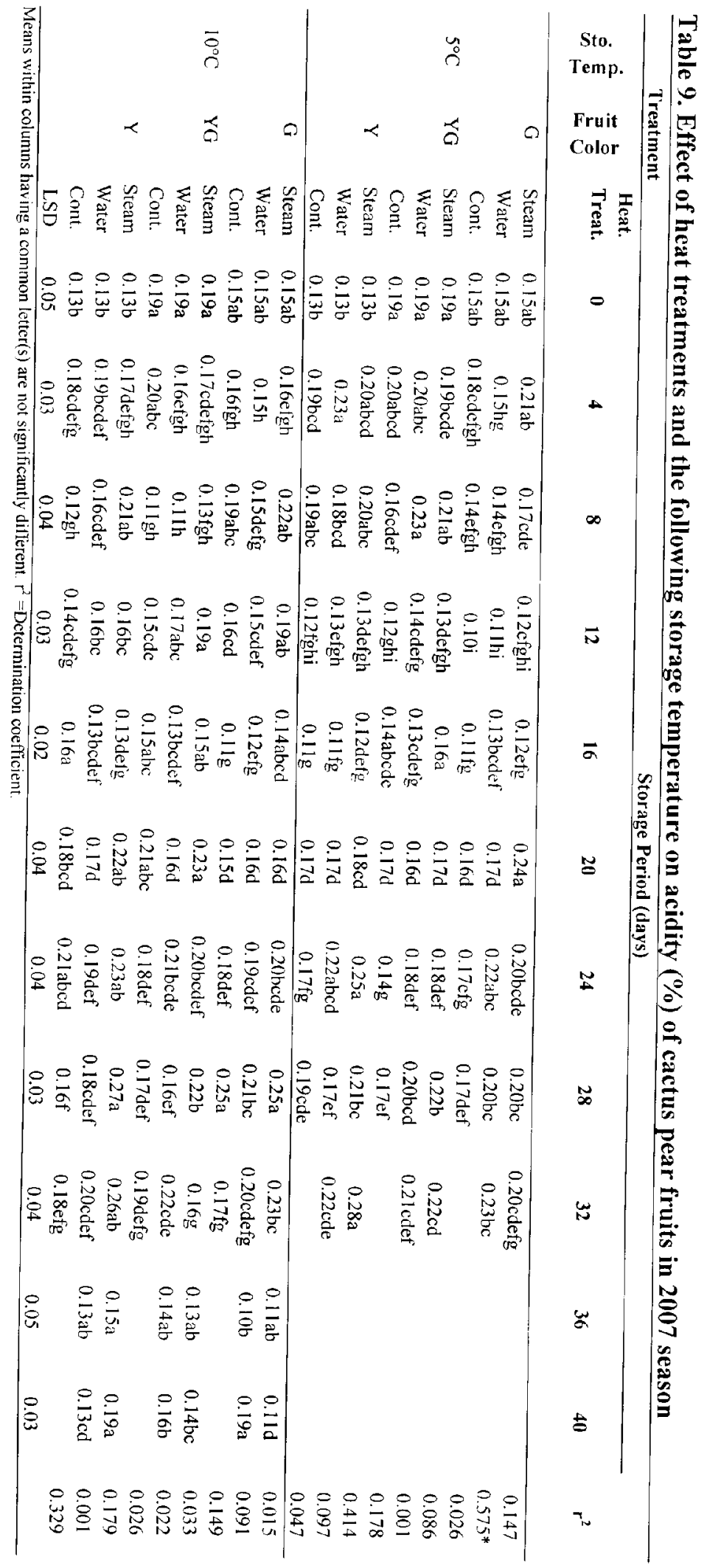




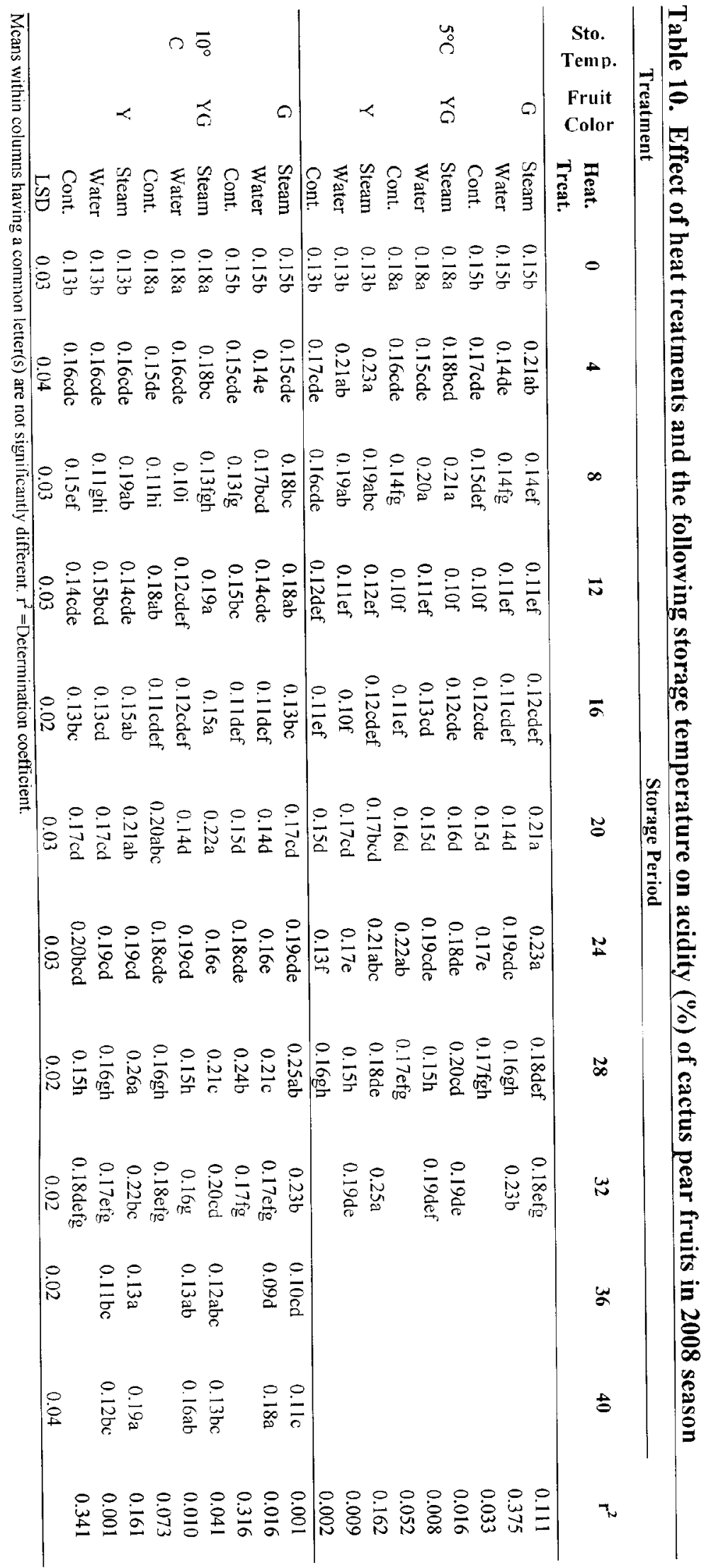




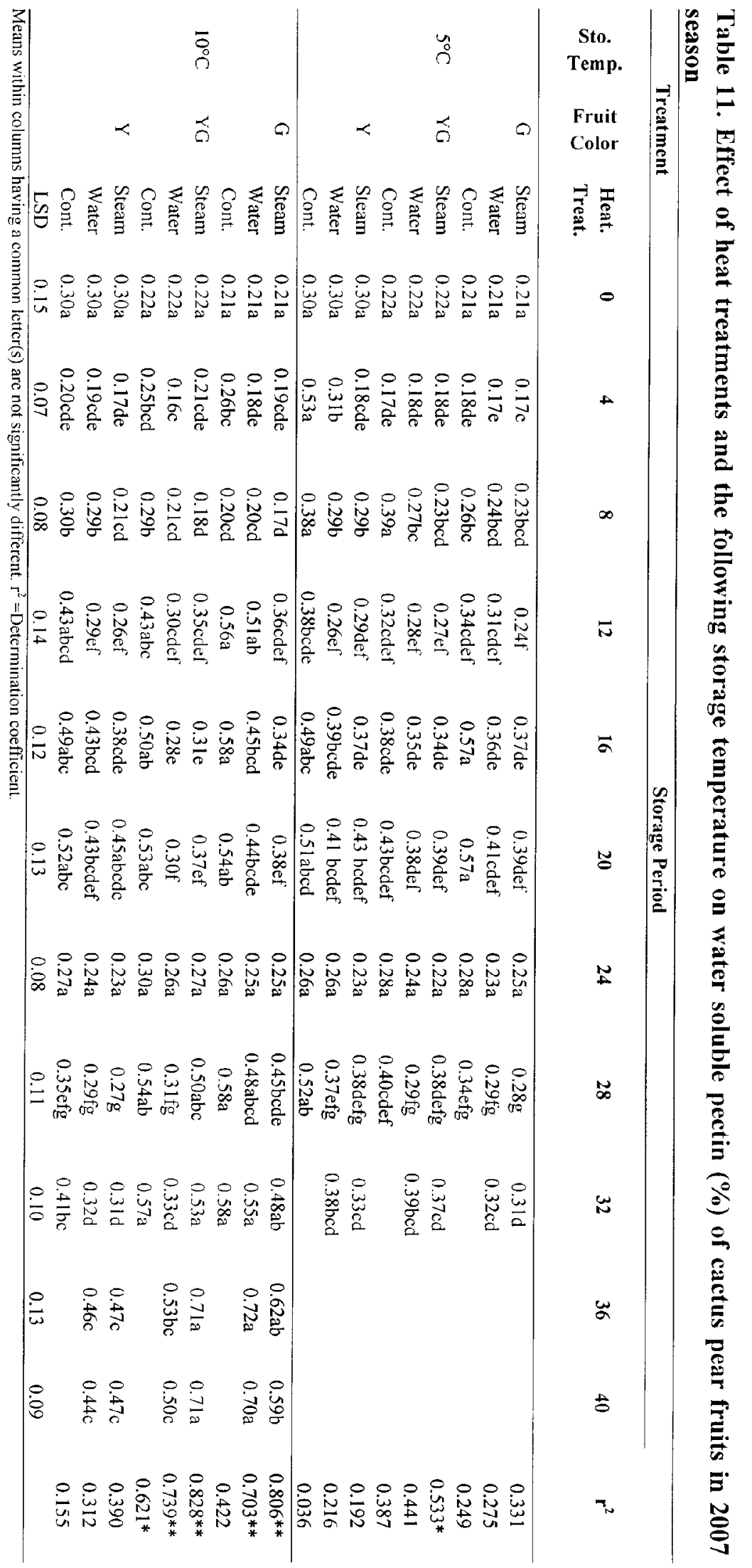




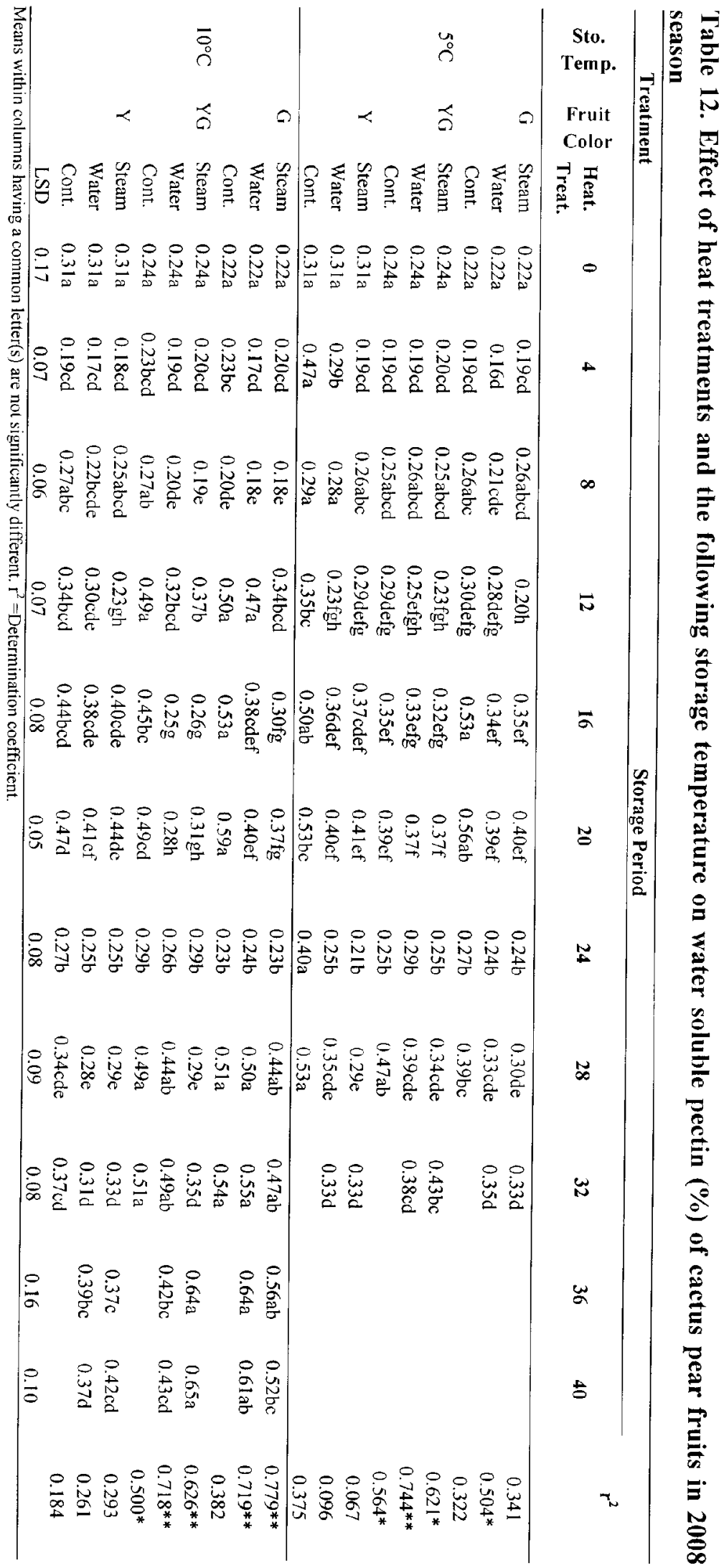




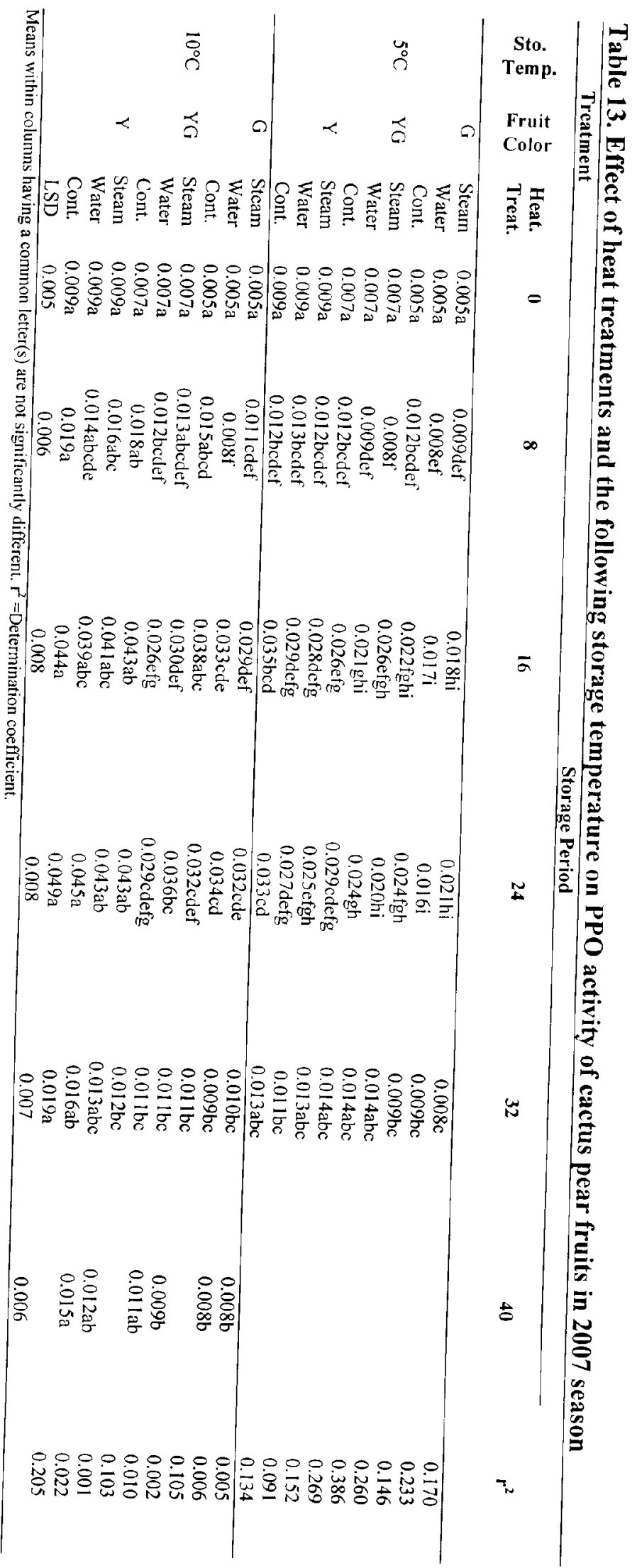




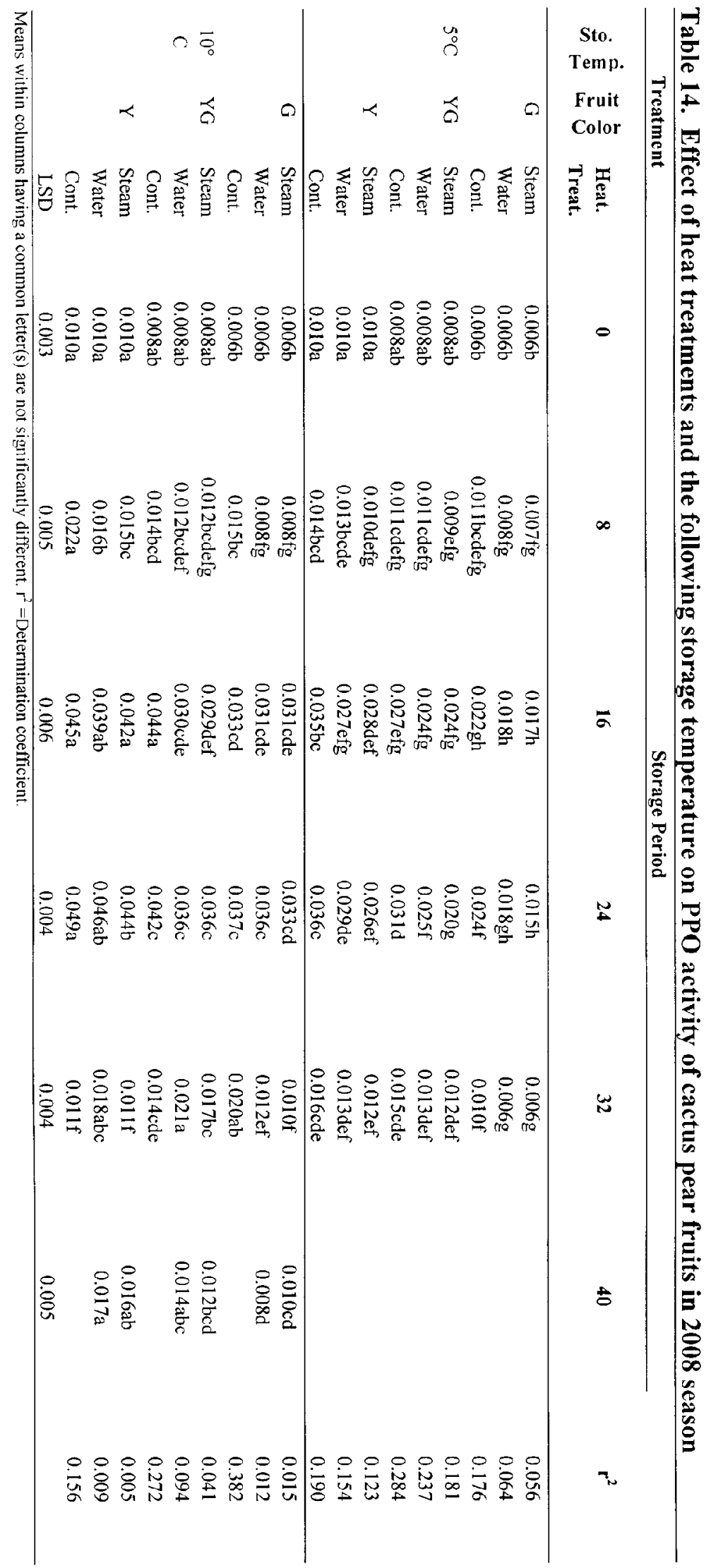


The above finding associated with those of Bicalho and Camargo, (1982) and Cantwell, (1995). On the other hand, Martinez-Olea, (1986) reported that WSP remained relatively constant during ripening of cactus pear fruits.

\section{Pulp PPO Activity:}

Tables 13 and 14 showed the obtained data of pulp PPO activity of cactus pear fruits (OD) The green fruits were the lowest in PPO activity at harvest and during cold storage. Heat treatments had significant effect on reducing the activity of PPO pulp enzyme and the differences were clear on the second season compared with unheated fruits. There were no significant differences between the two heat treatments in most intervals of the two seasons. With the advancing of cold storage PPO activity increased then decreased $\left(\mathrm{r}^{2}\right.$ values were not significant) after 24 days at 5 and 10 ?C due to the oxidation of phenolic compounds by PPO to form quinones that are lightly unstable and polymerize quickly.

The above results and discussion agree with those of Ingham et al., (1998) on apples, El-Saedy, (2000) on peaches and El-Saedy and El-Naggar, (2005) on guava.

Stintzing et al., (2001) reported that the presence of polyphenols in the juice is at the level of $393 \mathrm{mg} / \mathrm{kg}$ and it is very important for antioxidative properties.

\section{ACKNOWLEDGEMENT}

The author wish to express her thanks to the Alexandria Post-harvest Center, Pomology Department, Faculty of Agriculture (El-Shatby), Alexandria University for providing the necessary facilities, help and encouragement during the course of this work.

\section{REFERENCES}

Association of Official Agricultural Chemists (AOAC) (1980). Official methods of analysis. $13^{\text {th }}$ ed. Association of Official Analysis Chemists. Washington, D. C., USA.

Berger, H.; A. Mitrovic; L. Galletti and J. Oyarz?n (2002). Effect of hot water and wax application on storage life of cactus pear (Opuntia ficus indica L. Mill.) fruits. Acta Hort. (ISHS),581: 211 - 220.

Berger, H.; X. Ortuzar; C. Auda; A. Lizana and A. Reszczynski (1978). Conservaci?n de tunas (Opuntia ficus indica L. Mill.) en almacenaje refrigerado. Investigaci?n Agr?cola, 1 (4): 21 - 24.

Bicalho, U. de O.; M. de V. Camargo (1982). Estudo do fruto e do articulo da (Opuntia ficus indica L.) Miller cultivada em Valinhos, S. P. (C. F. Cantwell, M. (1995). Post-harvest management of fruits and vegetables stems. In: G. Barbera; P. Inglese and Y. E. Pimienta-Barrios (eds). Agro-ecology, cultivation and uses of cactus pear. FAO Plant Production Paper 132: 120 - 143).

Brenneman, J. A. and L. L. Black (1979). Respiration and terminal oxidases in tomato leaves infected by Phytophthora infestans. Physio. Pl. Path., 14: 281 - 290.

Cantwell, M. (1986). Post-harvest aspects of prickly pear fruits and vegetable cladodes. Perishable Handling, Unv. California, Davis, No. 59: 6 - 9.

Cantwell, M. (1995). Post-harvest management of fruits and vegetables stems. In: G. Barbera; P. Inglese and Y. E. Pimienta-Barrios (eds). Agro-ecology, cultivation and uses of cactus pear. FAO Plant Production Paper 132: $120-143$

Castillo, R. (1997). Estudio del comportamiento del fruto de tuna (Opuntia ficus indica L. Mill.) en condiciones de atm?sfera controlada. Tesis Ing. Agr., Santiago, Chile. Unv. De Chile, Fac. De Ciencias Agrarias y For. 47 p.

Chein, Y. W. (2000). Post-harvest techniques for reducing low temperature injury in chilling-sensitive commodities. IIR Conference October, Murcia, Spain.

Chen, P. M. and W. M. Mellenthin (1981). Effects of harvest date on ripening capacity and post-harvest life of d'Anjou pears. J. Amer. Soc. Hort. Sci. 106 (1): 38 - 42.

Chessa, I. and G. Barbera (1984). Indagine sulla frigoconservzione dei frutti della cv. Gialla di ficodindia. Rivista di frutticoltura, 8: 57 - 61.

Chessa, I.; Q. A. Cossu and D. Aquino (1992). Surface characteristics of prickly pear (Opuntia ficus indica Mill) fruit during development. In: Proc. $2^{\text {nd }}$ Inter. Cong. Prickly Pear and Cochineal, Unv. Chile, Santiago, Chile, pp 86 - 92.

Dominguez T. J. J., (1992). Efecto de laincidencia de danos por fr?o sobre la fisiolog? y calidad de frutos de tuna (Opuntia amyclaea T.). Tesis de Maestr?a. Colegio de Postgraduados. Montecillo, México.

Duru, B. and N. Turker (2005). Changes in physical properties and chemical composition of cactus pear (Opuntia ficus indica) during maturation. J. PACD, 22 33.

El-Naggar, N. I. and R. M. El-Saedy (2004). Effect of hot water treatment on reducing low temperature injury of papaya fruits. J. Agrec. Sci. Mansoura Univ., 29 (12): $7241-7253$.

El-Saedy, R. M. (2005). Cherimoya quality and storagability in response to heat treatment. Alex. J. Agric. Res., 50 (3): $109-119$.

El- saedy, R. M. and N. I. El-Naggar (2005). Effect of pre and post harvest calcium treatments on polyphenoloxidase and peroxidase activity of seedless guava fruits. Egyp. J. Appl. Sci., 20 (4): 224 - 231.

El-Saedy, R. M. (2000). Post-harvest-pre-storage calcium treatments in relation to quality changes and storagability of peaches. Ph. D. Thesis, Alex. Univ., Alex., Egypt. 
Felix, A. R. (2002). Post-harvest physiology and technology of cactus pear fruits and cactus leaves. Acta Hort. (ISHS), 581: 191 - 199.

Félix, R.; M. I. Gonz?lez-Salas; H. Soto-Valdez and M. I. Silveira-Gramont (1992). Effects of postharvest treatments on the quality of tuna during storage. Proc. $3^{\text {rd }}$ Ann. Texas Prickly Pear Conf., Texas Prickly Pear Council, McAllen, Tx.pp. 9 - 12.

Garcia, J. C.; J. A. Rodr?guez and E. B. Cruz (1997). Response of six cultivars of tuna fruits to cold storage. J. PACD, 160 - 168.

Gorini, F.; A. Testoni; R. Cazzola; F. Lovati; M. G. Bianco; I. Chessa; M. Schirra; M. Budroni and G. Barbera (1993). Aspetti tecnologici: Conservazione e qualità di fico d'india e avocado. L'Informatore Agrario. XLIX (1): 89 -92 .

Ingham, L. M.; M. L. Parker and K. W. Waldron (1998). Peroxidase: changes in soluble and bound form during maturation and ripening of apples. Physio. Plan., 102 (1): 93 - 100.

Lazan, H.; Z. M. Ali; K. S. Liang and K. L. Yee (1989). Polygalacturonase activity and variation in ripening of papaya fruit with tissue depth and heat treatment. Physiologia Plantarum 77 (1): 93 - 98 (C. F. Hort. Abst. 61: 10545, 1991).

Lopez, A. C.; A. C. Hernandez; F. G. Lara and O. P. Lopez (2003). Physio-chemical changes during ripening in storage of two varieties of prickly pear stored at 18 ?C. J. Food Technol., 40 (5): 461 - 464.

Martinez-Olea, O. R. (1986). Caracteristicas de calidad de tunas de diferentes selecciones de Opuntia cultivadas en el estado de Sonora. Professional Thesis, Univ. de Sonora, Hermosillo, Mexico. 54 pp. (C. F. Cantwell, M. (1995). Postharvest management of fruits and vegetables stems. In: G. Barbera; P. Inglese and Y. E. PimientaBarrios (eds). Agro-ecology, cultivation and uses of cactus pear. FAO Plant Production Paper 132: 120 143).

Matta, A. and A. E. Dimond (1963). Symptoms of fusarium in relation to quality of fungus and enzyme activity in tomato stems. Phytopath., 53: 574 - 575.

Mitcham, E. J. and R. E. McDonald (1993). Effects of quarantine heat treatment on mango fruit physiology. Acta Hort. 343: 361 - 366.

Ort?zar, X. (1976). Conservaci?n de tunas (Opuntia ficus indica L. Mill.) en almacenaje refrigerado. Tesis Ing. Agr., Santiago, Chile. Unv. De Chile, Fac. De Ciencias Agrarias y For. 59 p.

Paull, R. E. and R. E. McDonald (1994). Heat and cold treatments. In: Paull, R. E. and J. W. Armstrong (Eds), Insect Pets and Fresh Horticultural Product: Treatments and Responces. CAB International, Wallingford, UK, pp. 191-222.
Pérez, T. H.; A. C. L?pez; F. G. Lara; A. C. Hern?ndez and O. P. L?pez (2005). Biochemical and nutritional characterization of three prickly pear species with different behavior. Plant Food and Human Nutrition, 60 $195-200$

Piga, A.; A. Del Caro; I. Pinna and M. Agabbio (2003). Changes in ascorbic acid, polyphenol content and antioxidant activity in minimally processed cactus pear fruits. Lebensm-Wiss. U. Technol., 36: 257 - 262.

Piga, A.; G. D'hallewin; S. D'Aquino and M. Agabbio (1997). Influence of film wrapping and UV irradiation on cactus pear quality after storage. Pack. Techon. Sci., 10: 59 - 68 .

Piga, A.; S. D' Aquino; M. Agabbio and M. Schirra (1996). Storage life and quality attributes of cactus pears cv. Gialla as affected by packaging. Agr. Med., 126: 423 427.

Phillips, J. D. (1982). Changes in peaches after hot water treatment. Plant Disease, 66 (6): 487 - 488.

SAS (1985). SAS user' guide statistics for personal computers version $5^{\text {th }}$ ed. SAS Inst. Cary NCO.

Schirra, M.; G. Barbera; G. D'hallewin; P. Inglese and T. La Mantia (1997). Storage response of cactus pear fruit to $\mathrm{CaCl}_{2}$ preharvest spray and postharvest heat treatment. J. Hot. Sci., 72 (3): 371 - 377.

Schirra, M.; P. Inglese and T. La Mantia (1999). Quality of cactus pear (Opuntia ficus indica L. Mill.) fruit in relation to ripening time, $\mathrm{CaCl}_{2}$ pre-harvest sprays and storage conditions. Scientia Hort., 81: 425 - 436.

Shalom, N. B.; J. Hanzon; J. D. Klein and S. Lurie (1993). A post-harvest heat treatment inhibits cell wall degradation in apples during storage. Phytochemistry, 34 (4): 955 958. (C. F. Hort. Abst., 65 (7): 5655, 1995).

Silva, S. M.; M. F. Lopes; D. M. Brito Primo and L. B. V. Torres (2009). Pulp color changes during storage of cactus pear fruit coated with yam starch. Acta Hort. (ISHS), 811.

Snedecor, G. W. and W. G. Cochran (1980). Statistical Methods. $7^{\text {th }}$ Ed., $4^{\text {th }}$ Printing, the Iowa State Univ. Press Ames., Iowa U. S. A.

Stintzing, F. C.; A. Schieber and R. Carle (2001). Phytochemical and nutritional significance of cactus pear. Eur Food Res Technol, 212: 396 - 407.

Undurraga, P. L.; J. A. Olaeta and M. L. Marnich (1995). Effect of increasing nitrogen fertilizer rates on cherimoya (Annona cherimoya Mill) cv. Concha Lisa fruits in refrigerated storage. Amer. Soc. Agric. Eng., 405 - 413. (C. F. Hort. Abst., 65 (10): 9289, 1995).

Zainon, M. A.; C. H. Ng; S. T. Chua; L. M. Nor; R. Othman and H. Lazan (2000). Heat treatment alleviates chilling injury symptoms; retards texture changes and maintains the capacity to produce ethylene in papaya fruits. IIR Conference October, Murcia, Spain. 


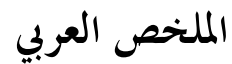

\section{تأخير ظهور أعراض أضرار البرودة وتقليل تدهور ثمار التين الشوكى أثناء التخزين المبرد باستخدام المعاملات الحرارية}

رجاء موسى الصعيدى، نرمين اسماعيل النجار

لجميع المعاملات و لم يكن هناك فروق معنويسـة بــين المعــاملات الحرارية. وفى كلا الموسمي فإن الثمار الصفراء أعطت أعلى نسبة من

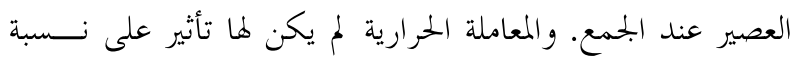

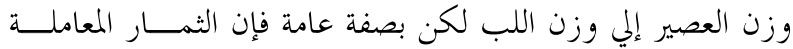
ببخار الماء أعطت أعلى وزن عصير ور.ما يرجع ذلك نتيجة لتقليل فقد الماء. وقد فقدت الثمار عصيريتها مع تقدم التخزين فيا عــــدا الثمار الخضراء ـ وعند الجمع فإن الثمار الصفراء كان لها أعلى قيم من المواد الصلبة الذائبة والبكتين الذائب في الماء ونشاط إنزيم البولي فينول أو كسيديز و أقل نسب من الحموضة. و لم يكن هناك تــأثير معنوي للمعاملات الحرارية على المواد الصلبة الذائبة ما عدا المحتوى

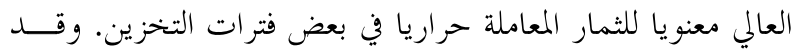
كان للمعاملات الحرارية تأثير معنوي على الحموضة خاصة المعاملة ببخار الماء والتي كان لها أعلى قيم في درجيت حرارة التخــزين وفي

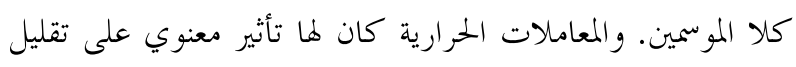
البكتين الذائب في لب الثمار والحموضة ونشاط إنزيم البولي فينول أو كسيديز. وقد قلت المواد الصلبة الذائبة في جميع المعاملات في كلا

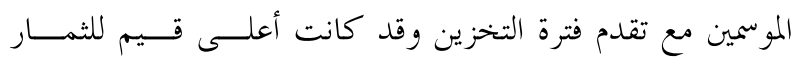

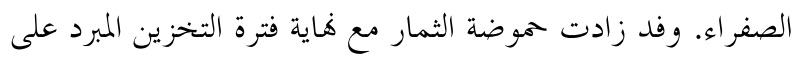

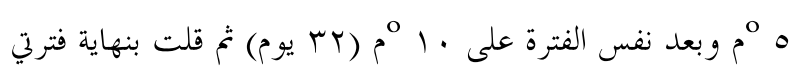
التخزين على • ا م. م. وقد إزداد محتوى الثمار من البكتين الذائب مع فقد الصلابة وقد كانت أقل نسبة تغير للثمار الصفراء و المخزنة

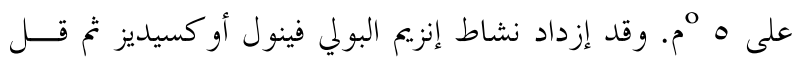

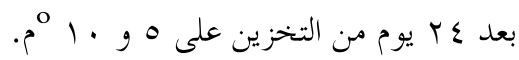

ثمار التين الشوكى لثلاث مراحل نضج هى الأخضر الفـــاتح والأخضر المصفر والأصفر تم معاملتها ببخار الماء عند VA م م تقريبا

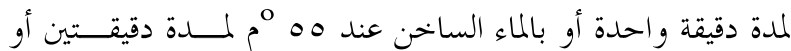
بالغسيل .ماء الصنبور فقط (الكنترول). كل من هذه البحاميع التسع (r مراحل نضج × r معاملات) تم تقسيمها الى قسمين الأولى تم

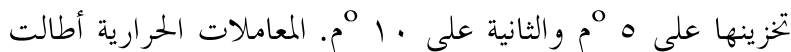
فترة التخزين لجميع مراحل نضج الثمار على ه و ـ ا إم على التوالي

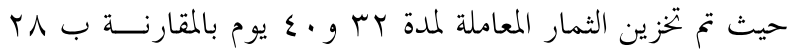
و rr يوم للكنترول. ثمار الكنترول كانت أول من بدأ ظهور العفن

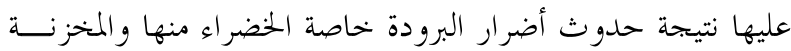

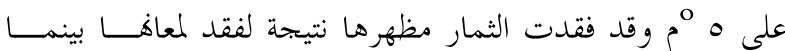
إحتفظت الثمار المعاملة حراريا بمظهرها الجيد الخالي مـــن العفــن والكرمشة لمدة أطول. وقد أخرت المعاملات الحرارية ظهور أعراض أضرار البرودة علي الثمار المخزنة على ه مج وقد كان أفضل مظهر للثمار بأقل أضرار تبريد هي الثمار الصفراء. والثمار المخزنة علــى • ا م مانت خالية من أعراض البرودة فيا عدا بعض البقع الحمراء

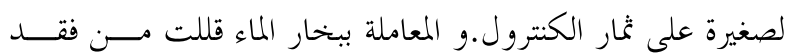
الوزن لثمار التين الشوكى و كانت الفروق معنوية للثمار الخـــضـراء المصفرة فيما عدا المخزنة على ه ْم في الموسم الأول. ومن ناحيـــة

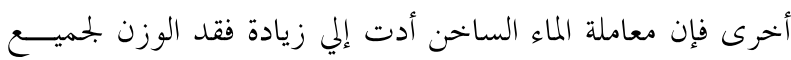
المعاملات بفروق غير معنوية مقارنة بثمار الكنترول لكنها قللت من فقد الوزن للثمار الخضراء المصفرة في الموسم الثاني. و الثمار الخضراء كان ها أعلى دليل لون و المعاملة الحرارية لم تؤثر على دليل اللون 
